
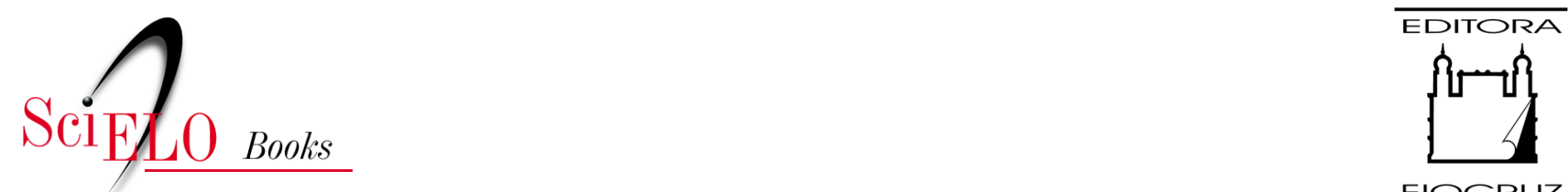

FIOCRUZ

\title{
4. Segmentos institucionais de gestão em saúde descrição, tendências e cenários prospectivos
}

\author{
Ana Luiza d'Ávila Viana \\ Alcides Silva de Miranda \\ Hudson Pacifico da Silva
}

\section{SciELO Books / SciELO Livros / SciELO Libros}

VIANA, A.L.D., MIRANDA, A.S., and SILVA, H.P. Segmentos institucionais de gestão em saúde: descrição, tendências e cenários prospectivos. In: NORONHA, J.C., LIMA, L.D., CHORNY, A.H., DAL POZ, M.R., and GADELHA, P., eds. Brasil Saúde Amanhã: dimensões para o planejamento da atenção à saúde [online]. Rio de Janeiro: Editora FIOCRUZ, 2017, pp. 151-188. ISBN: 978-65-5708090-0. https://doi.org/10.7476/9786557080900.0006.

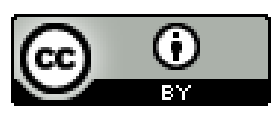

All the contents of this work, except where otherwise noted, is licensed under a Creative Commons Attribution $\underline{4.0 \text { International license. }}$

Todo o conteúdo deste trabalho, exceto quando houver ressalva, é publicado sob a licença Creative Commons Atribição 4.0.

Todo el contenido de esta obra, excepto donde se indique lo contrario, está bajo licencia de la licencia $\underline{\text { Creative }}$ Commons Reconocimento 4.0. 


\title{
SEGMENTOS INSTITUCIONAIS DE GESTÃO EM SAÚDE: DESCRIÇÃO, TENDÊNCIAS E CENÁRIOS PROSPECTIVOS
}

\author{
Ana Luiza d'Ávila Viana \\ Alcides Silva de Miranda \\ Hudson Pacifico da Silva
}

Nos últimos 25 anos, dois fenômenos emergem com força na política de saúde, com impactos distintos segundo regiões e estados brasileiros: primeiro, a descentralização da formulação, gestão e implementação da política de saúde; segundo, o crescimento do número e tipo de atores envolvidos com a oferta e gestão de serviços, de forma a incrementar tanto o papel e a importância de atores não governamentais nas atividades envolvidas com a implementação de políticas e ações quanto o surgimento de diversos tipos de empresariamento da gestão e oferta de serviços. Ao mesmo tempo, as ideias gerencialistas (ênfase nas ações de melhor custo-benefício) para a governança operacional ${ }^{1}$ do sistema de saúde foram difundidas e passaram a ter centralidade na política.

Esses dois fenômenos, a descentralização do poder regulatório e decisório para os níveis subnacionais de governo e a proliferação das atividades de empresariamento da oferta de serviços, foram contemporâneos e estratégicos para a conformação de um sistema nacional de saúde e introduziram ciclos diferenciados ao longo da trajetória de implementação do Sistema Único de Saúde (SUS) - um ciclo que cobre os anos 1990, voltado para incrementar a descentralização com foco nos municípios; e outro, já nos anos 2000, de maior ênfase na estratégia de regionalização de forma a superar os entraves advindos das grandes desigualdades na oferta de serviços.

Resta saber como os dois fenômenos se inter-relacionam e, mais importante, o que explica o surgimento do segundo fenômeno, tendo em vista a vasta literatura nacional e internacional sobre o protagonismo dos processos de descentralização nas reformas dos sistemas de saúde, desde a década de 1980, porém com poucas menções sobre o segundo fenômeno e hipóteses sobre a sua contemporaneidade com o processo de descentralização, no caso da literatura nacional. Já a literatura internacional enfatiza a crescente importância do nível local e sua relação com atores horizontais e verticais, com mudança na relação local-nacional, desburocratização e um formato organizacional menos hierárquico e mais reticular e horizontal ou com delegação para as organizações privadas, que aumentaram seu protagonismo como forças/atores relevantes nas políticas de proteção social.

\footnotetext{
${ }^{1}$ Governança operacional, diretiva e constitutiva (Hupe \& Hill, 2006) se refere a diferentes funções no processo (de conformação) das políticas públicas. Constitutiva se refere à formulação de um arcabouço jurídico e institucional; diretiva, ao processo decisório; e operativa, ao processo de prestação dos serviços.
} 
A construção dessa governança multinível² ocorre em diversos tipos de relações intra e interinstituições, como devolução (para um ente subnacional), governo conjunto (joint-up government) ou governo holístico (whole-of-government), quando se inicia na esfera pública e transborda para outros atores, na forma de uma governança compartilhada (shared governance). Com isso, o tradicional modelo burocrático hierárquico, com base em cadeias de comando e na separação de competências e responsabilidades, deixa de ser o único formato que rege as relações intra e interinstitucionais, ao mesmo tempo que emergem relações de rede (negociação, contratos e consórcios) e de mercado.

A coordenação das políticas passa a ser a grande preocupação, tendo em vista que as regiões e o local são perpassados por três tipos de relação intra e interinstitucional: a governança burocrática hierárquica (papel da autoridade pública para definir prioridades e fronteiras de direito); a governança de rede (relação entre público e privado social) e a governança de mercado (relação entre público e privado de mercado).

Aqui estamos trabalhando com o conceito de governança elaborado por Richard e Smith (2002), que a define como um instrumento para iluminar a mudança de natureza do processo político nas décadas recentes, em particular a entrada de múltiplos atores na ação de fazer políticas públicas. Esse conceito é completado pela definição de Milward e Provan (2000), para quem a governança objetiva criar mecanismos - recursos, contratos e acordos - complementares à autoridade e às sanções da esfera pública. Dessa forma, o uso do conceito de governança auxilia na compreensão das múltiplas variáveis e multiníveis de ações que influenciam o desempenho de uma determinada política pública.

Uma linha forte de argumento relaciona os dois temas - descentralização e empresariamento - com o enfraquecimento do poder do Estado nacional, o advento de profundas modificações nas economias capitalistas (com aprofundamento da globalização) e a hegemonia das ideias neoliberais. Outro aspecto também destacado é a crescente importância da new public management (NPM) nas formas de organização do setor público, como será destacado mais adiante.

As mudanças no sistema econômico, particularmente o crescimento dos serviços, a internacionalização dos circuitos produtivos, a intensificação dos processos de concentração, financeirização e internacionalização do setor de serviços, bem como as mudanças no mercado de trabalho e em aspectos sociodemográficos, respondem, em parte, pelas inadequações dos sistemas de saúde e o surgimento de novas necessidades, forçando reformas importantes na forma de organização e prestação dos serviços de saúde.

A literatura internacional é pródiga em relacionar descentralização e o empresariamento com os fenômenos mencionados anteriormente, de forma a caracterizar o sistema de proteção social como fragmentado - do ponto de vista institucional -, heterogêneo e desigual, do ponto de vista territorial e em razão da perda de importância dos mecanismos de governança burocrática-hierárquica sob comando estatal.

\footnotetext{
${ }^{2}$ Governança multinível (ou de múltiplos níveis) enfatiza o compartilhamento de poder entre níveis de governo com nenhum centro de autoridade acumulada e cujas relações são caracterizadas pela interdependência mútua de recursos de todos - e não pela competição por recursos escassos (Smith, 2010).
} 
Para o Brasil e, em particular, para a política de saúde, o que nos parece vital é ter uma perspectiva integrada para análise dos dois fenômenos (descentralização e empresariamento), de modo a compreender sua presença diferenciada no território nacional, seus ciclos de expansão e seus condicionantes histórico-estrutural, político-institucional e conjuntural, e, principalmente, desenhar cenários futuros.

Nossa tarefa aqui é de outra ordem: relacionar na área da saúde esses dois processos no intuito de discutir a evolução futura dos modelos de gestão levando em consideração as variáveis que influenciam ambos os processos e são capazes de identificar e localizar situações ou tipos de descentralização e empresariamento presentes no território nacional.

São importantes as variáveis histórico-estruturais (de path dependence), ao lado do desenvolvimento de governanças multiníveis no processo de descentralização e empresariamento, que conformam situações de maior ou menor presença da esfera privada, de relações de rede e de mercado e de legitimidade e afirmação do modelo burocrático sobre os demais (ou não).

A seguir elencamos três variáveis que influenciam os modelos de gestão em saúde:

- aspectos de path dependence na relação público-privada na oferta de serviços de saúde e evolução recente;

- governança constitutiva e diretiva do sistema de saúde (incentivo à conformação de novos tipos de arranjos público-privados, alcance da regulação e pertinência dos instrumentos regulatórios);

- conjunturas específicas e locais nas quais se destaca a questão do (sub)financiamento (custeio e investimento) do sistema de saúde nos níveis locais e regionais.

A pergunta pertinente é se o empresariamento foi apoiado por um forte processo normativo nacional ou se deve a políticas estaduais, fortemente presentes em alguns períodos específicos, vinculadas (ou não) a coalizões políticas estaduais de espectro ideológico definido. Também cabe perguntar qual é o papel da regulação pública estatal nesse processo, isto é, a governança constitutiva e diretiva foi expandida por meio de instrumentos regulatórios próprios e de amplo consenso social e político?

Do ponto de vista das variáveis vinculadas ao path dependence, temos uma configuração histórica de predomínio da oferta privada (internação) nos estados do Sul do Brasil, em oposição a um protagonismo da presença pública no extremo oposto, estados do Norte e Nordeste do país, e uma situação intermediária, de presença mista, pública e privada, nos estados do Sudeste. ${ }^{3}$ Esse é um padrão histórico, e se o poder explicativo da variável path dependence for forte, o empresariamento estaria mais presente nas regiões Sul e Sudeste - e teria baixa penetração nos estados do Norte e Nordeste. Por outro lado, os incentivos (traduzidos em leis e decretos estaduais e municipais) para

\footnotetext{
3 Dados para 2012 indicam que 83,5\% das internações no Norte e Nordeste, onde vivem 35\% da população brasileira, são realizadas por instituições públicas; no Sul, ao contrário, as internações privadas são maioria e somente 7,5\% das internações ocorrem em entidades públicas (reside nessa macrorregião brasileira 21\% da população); já no Sudeste, as internações públicas configuram 46,1\%, portanto uma oferta mista, e ali residem $43 \%$ da população brasileira (Viana et al., 2013).
} 
criação de novos arranjos público-privados tiveram início nos estados do Sudeste, ${ }^{4}$ porém em anos recentes (pós-2004) houve difusão desse modelo para alguns estados do Nordeste (Bahia, Sergipe e Pernambuco) e do Norte (Roraima, por exemplo).

Há proliferação de microacordos (particularistas e clientelistas) por todos os estados sem regras claras de desempenho, metas e eficiência na contratualização dessas entidades privadas, como característica forte em algum estado ou região específica.

A criação de instrumentos regulatórios também não se destaca em nenhum nível de governo e mesmo as atuais deliberações nacionais para a estratégia de regionalização só indicam que deva ser incluído o setor privado nas atividades de planejamento, mas não enseja a criação, em todas as instâncias, de instrumentos claros de regulação e mesmo de sanção/punição e incentivo (prêmio).

A questão do financiamento se distingue regionalmente, no tocante ao financiamento de custeio, porém é uma constante a baixa participação do investimento no gasto público em saúde. Os estados que se destacam no alto financiamento estadual da política de saúde estão localizados nas regiões Norte e Sudeste (ênfase para São Paulo e Tocantins): já o alto financiamento municipal se encontra nos estados da região Centro-Oeste (tanto Mato Grosso quanto Mato Grosso do Sul), e também na região Sudeste, nos estados de São Paulo, Rio de Janeiro e Minas Gerais.

Portanto, níveis altos ou baixos de financiamento estadual não influenciam as decisões de empresariamento. Da mesma forma, tanto o alto ou baixo financiamento municipal pode influenciar a adoção de processos de contratualização para oferta e gestão dos serviços de saúde. Isto é, o financiamento não é uma variável forte de explicação desse processo porque ele pode ocorrer nos dois extremos do ciclo - períodos de alta e baixa disponibilidade de recursos.

A voz corrente associa o processo de empresariamento ao problema de escassez de recursos, porém, como pode ser visto, o mesmo acontece em todas as situações, seja na esfera estadual ou municipal. Pode ser que o início do processo tenha ocorrido em situações de dificuldades para as finanças estaduais e/ou municipais (segunda metade dos anos 1990), como parece ser o caso de São Paulo, porém, há estudos, mesmo para o estado de São Paulo, nos quais se demonstram que as decisões foram influenciadas por um quadro mais complexo do que o problema financeiro isoladamente. ${ }^{5}$

O Quadro 1 a seguir sintetiza as situações das variáveis utilizadas, fruto de pesquisa com dados secundários extraídos de pesquisas recentes e fontes diversas, como teses e artigos. Da mesma forma, a pesquisa empírica desse texto informa a construção do quadro-resumo.

As variáveis com maior força explicativa são aquelas referentes ao processo de governança constitutiva (incentivo jurídico institucional para criação de novos arranjos) e a questão do baixo investimento público para ampliação da capacidade instalada, principalmente na área hospitalar e de serviços de apoio diagnóstico e terapêutico (SADT). De todo modo, a descentralização foi peça importante para o surgimento do fenômeno do empresariamento porque concedeu grau de autonomia para as esferas subnacionais de governo no tocante a formulação, gestão e implementação de políticas.

\footnotetext{
${ }^{4}$ Em São Paulo, a primeira Organização Social de Saúde é de 1995.

${ }^{5}$ Conferir Pahim (2009).
} 
Quadro 1 - Resumo das variáveis que influenciam os modelos de gestão

\begin{tabular}{|c|c|c|c|c|c|}
\hline \multirow{2}{*}{ Variável } & \multicolumn{5}{|c|}{ Regiões } \\
\hline & Norte & Nordeste & Centro-Oeste & Sudeste & Sul \\
\hline Path Dependence ${ }^{6}$ & Público & Público & Público & Misto & Privado \\
\hline $\begin{array}{l}\text { Governança } \\
\text { constitutiva } \\
\text { (incentivo à criação } \\
\text { de novos arranjos } \\
\text { público-privado) }\end{array}$ & Fraca & Média & Média & Forte & Forte \\
\hline $\begin{array}{l}\text { Governança diretiva } \\
\text { (regulação) }\end{array}$ & Fraca & Fraca & Fraca & Média & Média \\
\hline $\begin{array}{l}\text { Governança } \\
\text { operacional } \\
\text { (mecanismos de } \\
\text { regulação) }\end{array}$ & Fraca & Fraca & Fraca & Fraca & Fraca \\
\hline $\begin{array}{l}\text { Financiamento } \\
\text { regional e local } \\
\text { (investimento) }\end{array}$ & Baixo & Baixo & Baixo & Baixo & Baixo \\
\hline $\begin{array}{l}\text { Financiamento } \\
\text { regional e local } \\
\text { (custeio) }^{7}\end{array}$ & $\begin{array}{c}\text { Estadual } \\
\text { elevado e } \\
\text { municipal baixo }\end{array}$ & $\begin{array}{l}\text { Médio e baixo } \\
\text { estadual e } \\
\text { médio e baixo } \\
\text { municipal }\end{array}$ & $\begin{array}{l}\text { Baixo estadual } \\
\text { e elevado } \\
\text { municipal }\end{array}$ & $\begin{array}{l}\text { Estadual elevado } \\
\text { e elevado e } \\
\text { médio municipal } \\
\text { (exceção: RJ e } \\
\text { MG, de baixo } \\
\text { estadual e elevado } \\
\text { municipal) }\end{array}$ & $\begin{array}{c}\text { Médio ou } \\
\text { baixo estadual } \\
\text { e médio } \\
\text { ou baixo } \\
\text { municipal }\end{array}$ \\
\hline
\end{tabular}

Diante desse quadro, como desenhar cenários futuros que possam alterar o quadro atual ou mantê-lo de forma semelhante ou agravado?

Um primeiro cenário, otimista, pode vislumbrar as possibilidades de incremento do investimento público com maior autossuficiência em capacidade instalada, instalação de regras mais claras de controle e supervisão do processo de empresariamento e anulação ou neutralização dos aspectos clientelísticos, particularistas e locais na contratualização de entidades privadas. Por outro lado, teríamos uma melhor legitimidade do modelo burocrático em conjunto com o modelo de rede e a consequente diminuição da participação do modelo mercado. Esse cenário pressupõe o aprofundamento do processo de regionalização e a criação de regras claras de corresponsabilidades no planejamento regional. A coordenação da gama de instituições e atores pode ser facilitada pelo reforço e pela criação de instrumentos de contratualização administrados por novos espaços interinstitucionais.

Tal cenário é altamente dependente dos seguintes fatores: expansão do investimento público; criação e reforço da governança em rede e burocrática; qualificação de novos instrumentos de planejamento territorial, de forma a diminuir o grau de fragmentação, o desperdício e a heterogeneidade; aprofundamento do processo de regionalização na saúde; e apoio forte dos estados nesse processo.

\footnotetext{
${ }^{6}$ Ver Viana e colaboradores (2013).

7 Dados extraídos de Levi e Scatena (2011).
} 
No extremo oposto, a regionalização não se implementa de forma forte e a fragmentação passa a ser o traço dominante do sistema. O baixo investimento público impede o recuo do processo de empresariamento para oferta de serviços, e microcontratos se proliferam sem regras claras e ao sabor das decisões das elites locais, com baixo consenso social e político. O modelo de mercado se torna predominante e o papel das redes, assim como a gestão burocrática, se enfraquece.

A situação intermediária seria constituída pela adoção do primeiro modelo em algumas regiões e estados, e o segundo nas regiões mais pobres do país, mantendo uma dualidade ao longo do território, o que é característico de alguns sistemas de saúde europeus - forte regulação no Norte e no Centro, com algum grau de participação privada na oferta e gestão de serviços; e baixa regulação, em situações de baixa e alta participação do setor privado, no Sul do país (como acontece na Itália, por exemplo).

Apresentamos, a seguir, o percurso utilizado para a identificação desses cenários: uma breve revisão bibliográfica para contextualizar as mudanças ocorridas no âmbito do Estado no período recente e seus reflexos nos sistemas de saúde; um levantamento empírico com base nos dados disponíveis no Cadastro Nacional de Estabelecimentos de Saúde (CNES) para definir os segmentos institucionais de gestão em saúde no Brasil; e, finalmente, os prováveis cenários para os tipos identificados.

\section{Mudanças nas Funções do Estado Contemporâneo e suas Implicações para a Gestão Pública e os Sistemas de Saúde}

O conjunto das transformações ocorridas no âmbito do Estado nos últimos trinta anos está relacionado à crise de um determinado padrão de intervenção estatal, que se consolidou após a Segunda Guerra Mundial e entrou em declínio a partir da década de 1970, por conta da perda de dinamismo das principais economias ocidentais. Esse padrão foi marcado por políticas ativas de intervenção estatal, com o objetivo de promover crescimento econômico e, ao mesmo tempo, assegurar níveis mínimos de equidade por meio de políticas de acesso a bens e serviços públicos mediante a construção de uma ampla rede de proteção social.

Essas políticas passaram a ser duramente criticadas nas últimas décadas do século XX. Em sua essência, as críticas enfatizavam a ineficiência da intervenção estatal na atividade econômica, identificando a imperfeição do Estado como parte fundamental do problema. Essa imperfeição, por sua vez, estava associada à própria natureza do Estado, constituído por um grande número de atores com interesses próprios e comportamento caracterizado por estratégias de maximização de interesses pessoais, tornando o próprio Estado refém desses interesses, nem sempre coincidentes com os da sociedade.

Questões relacionadas à delimitação do tamanho do Estado, à redefinição do seu papel regulador, ao fortalecimento da capacidade de implementar adequadamente as políticas públicas e ao aumento da capacidade política de governar passaram a integrar a agenda de reformas nos anos 1980 e 1990. Essas quatro questões seriam justificadas pela própria crise de legitimidade do Estado, cujas manifestações mais evidentes seriam a crise fiscal, o esgotamento do modo de intervenção estatal na atividade econômica e a superação da forma burocrática de administrar as organizações públicas. 
A redução do tamanho do Estado deveria ser feita mediante programas de privatização de empresas estatais que atuavam nas atividades de produção de bens e serviços para o mercado, transferência de serviços sociais e científicos para associações civis sem fins lucrativos (publicização) e terceirização das atividades auxiliares e de apoio. A redefinição do seu papel regulador estaria associada à adoção de mecanismos para reduzir o custo do cumprimento das regulamentações para o setor privado, ao mesmo tempo que se buscaria tornar mais transparentes as regras de funcionamento dos mercados, estimulando assim sua eficiência. Já a questão da governança estatal estava associada à resolução da crise fiscal do Estado, ao fortalecimento das instituições públicas responsáveis pela formulação e execução das políticas e à modernização e eficiência da administração pública. Finalmente, o aumento da governabilidade seria alcançado por meio de instrumentos capazes de elevar a legitimidade do Estado perante a sociedade e da adequação das instituições políticas para a intermediação dos interesses (Pereira, 1997).

Reformar o Estado e suas instituições se tornou então requisito para se alcançar padrões de governabilidade e governança na maioria dos países desenvolvidos. A busca pelo êxito na promoção de padrões mais eficientes de gestão fiscal e maior redistribuição de recursos e responsabilidades moldou os contornos das políticas de reforma do Estado nos países da OCDE (Rezende, 2005). Programas nacionais de reforma - como o National Performance Review, nos Estados Unidos, e o Next Steps, na Inglaterra - fundaram as bases do discurso gerencialista, de acordo com o qual a busca pela eficiência (fazer mais com menos) se tornou condição fundamental para a organização e o funcionamento do Estado. Do ponto de vista operacional, as mudanças institucionais desencadearam um conjunto amplo de reformas, voltadas para: a emergência e o desenvolvimento de políticas de reformulação da administração pública, das relações trabalhistas, do Judiciário, do Legislativo e dos mecanismos regulatórios; a modernização tributária; os programas massivos de privatização; e a revisão das relações entre governos centrais e subnacionais, especialmente em países organizados de forma federativa. ${ }^{8}$

Essas mudanças estão alinhadas com os preceitos da NPM, que consiste na transferência de conceitos, ferramentas e técnicas de gestão do setor privado para o setor público (Ferlie et al., 1999). As reformas nos países centrais, inspiradas nos modelos e preceitos da NPM, geraram resultados bastante diversos, tendo sido marcados por conflitos estruturais que derivaram da própria formulação e implementação dessas políticas. Embora os exemplos de países como Estados Unidos e Inglaterra tenham se tornado paradigmáticos, a realidade mostra que os Estados mais ricos continuaram a exibir padrões marcados por forte intervenção social e econômica, a despeito de uma retórica de reforma (Rezende, 2005).

Ainda que os preceitos da NPM tenham obtido grande centralidade no período recente, autores como Osborne (2010) entendem que ela representa um estágio transitório na trajetória de evolução entre a administração pública tradicional e a nova governança pública. O argumento central é que a

\footnotetext{
${ }^{8}$ Autores como Majone (1999) destacam que esse processo foi marcado por uma progressiva substituição do Estado positivo (intervencionista) por um Estado regulador, isto é, uma alteração da própria forma de regulação, uma vez que a regulação baseada na propriedade pública estatal, historicamente adotada por muitos países para o desenvolvimento de setores caracterizados como monopólios naturais, passou a ser substituída pela regulação por delegação, na qual o poder decisório é delegado para instituições independentes, como é o caso das agências reguladoras, que formulam e aplicam regras para o funcionamento desses mercados.
} 
implementação das políticas públicas e a prestação de serviços públicos passaram por três regimes diferentes: administração pública tradicional, baseada no modelo burocrático de administração, predominante do final do século XIX até meados dos anos 1980 nos países desenvolvidos; new public management, associada ao modelo gerencialista de administração, cujas diretrizes passaram a predominar a partir dos anos 1990; e nova governança pública, correspondente a um modelo pluralista de administração, que estaria no centro da discussão a partir do século XXI. ${ }^{9}$

\section{Reflexo das Reformas nos Modernos Sistemas de Proteção Social e de Saúde}

As transformações ocorridas no âmbito do Estado colocaram em discussão a pertinência dos sistemas de proteção social consolidados durante o século XX nos principais países desenvolvidos. Para Mérrien (1994), a crise financeira do Estado, impondo limitações para a base de financiamento dos gastos sociais, estaria na origem da chamada crise do Estado de bem-estar social (welfare state), cujo desenvolvimento histórico pode ser decomposto em três períodos distintos: construção e desenvolvimento; estabilidade; e crise.

A fase de construção teria se iniciado no fim do século XIX, podendo ser descrita como uma fase de emergência e de elaboração de novos paradigmas das políticas sociais, com discussões sobre os limites da proteção social, as categorias sociais que deveriam ser beneficiadas, o montante das contribuições, os riscos que deveriam ser cobertos e o modo de gestão do sistema. A fase seguinte, de estabilização, teria começado após a Segunda Guerra Mundial, marcada pela expansão dos mecanismos de proteção social em praticamente todos os países desenvolvidos, amparada por políticas econômicas de ampliação dos gastos públicos e situação de pleno emprego. Finalmente, a fase da crise teria iniciado na década de 1980, com a ascensão do pensamento neoliberal, num contexto caracterizado pela crise financeira dos Estados e pela emergência de problemas globais (e não setoriais).

Alguns resultados dessa crise foram documentados por Pierson (1998), que identificou mudanças nos benefícios sociais para os países da OCDE ao longo das décadas de 1980 e 1990. Dentre as mudanças identificadas pelo autor, destaca-se a retração de titularidades no valor dos benefícios (queda no valor real), no acesso aos programas (adoção de testes de meios e critérios mais duros de elegibilidade) e na introdução de formas de copagamento para utilização dos serviços. Ainda que essas mudanças não tenham sido implementadas igualmente por todos os países, elas abrangeram muitas áreas de intervenção do Estado na área social: aposentadorias (aumento da idade para se aposentar, extensão do período para requerer aposentadoria plena, redução da base para ajuste dos benefícios com base na inflação e teste de meios para aposentadoria); incapacidade (testes mais estritos de incapacidade, novos limites de duração e benefícios reduzidos); desemprego (elegibilidade reduzida e redução na duração e no nível dos benefícios); e benefícios para famílias (valor real declinante e elegibilidade decrescente).

\footnotetext{
${ }^{9}$ O autor reconhece que se trata de uma simplificação teórica, na medida em que elementos de cada regime ou modelo podem e vão coexistir ou se sobrepor aos elementos de outros.
} 
Apesar do constrangimento financeiro imposto às políticas sociais, diversos autores questionam o suposto desmantelamento ou recuo dos sistemas de proteção social dos países centrais em razão das políticas de ajuste macroeconômico. Draibe e Henrique (1988), em artigo no qual analisam a contribuição de diversos autores para o entendimento da crise do welfare state, argumentam que, apesar das pressões por mudanças, não é possível afirmar que houve esgotamento de uma dada forma de intervenção social do Estado. Já Pierson (1994) destaca que o alto grau de consolidação dos benefícios sociais nos países centrais (grau de enraizamento das políticas sociais nas diferentes sociedades) possibilitou a formação de uma ampla rede de interesses que foi capaz de minimizar ou mesmo neutralizar as tentativas de mudanças propostas pela agenda de reforma dos anos 1990 . Por outro lado, indicadores relativos ao montante e à composição do gasto social ${ }^{10}$ revelam que, ao contrário do esperado, houve expansão do gasto social público nas últimas décadas, além de relativa estabilidade na dimensão qualitativa do gasto (Castles, 2004). ${ }^{11}$

Os sistemas de saúde também foram afetados, em alguma medida, pela crise do Estado e dos sistemas de proteção social. De fato, a literatura sobre o tema identifica a existência de duas ondas de reformas nos sistemas de saúde, distintas em sua natureza: as reformas dos anos 1970-80, impulsionadas pelo imperativo macroeconômico de controle das despesas nacionais com o setor Saúde, e a agenda de reformas da década de 1990, cujas características estão associadas ao estabelecimento de inovações capazes de criar um ambiente institucional favorável à melhoria da eficiência dos prestadores de serviços de saúde.

Dado o quadro mais geral da crise dos sistemas de saúde, muitos países migraram de um modelo verticalizado para um modelo contratual de financiamento e provisão dos serviços, o que serviu como um estímulo complementar às políticas de controle de gastos no nível macroeconômico, gerando iniciativas de fortalecimento da eficiência e da capacidade de resposta aos usuários no nível microeconômico (Ham, 1997). A introdução de mecanismos mais alinhados com o mercado, o fortalecimento da gestão dos serviços de saúde e a adoção de incentivos orçamentários para melhorar o desempenho foram as principais medidas empregadas para a implementação dessas políticas.

O crescimento contínuo dos gastos com bens e serviços de saúde nas últimas décadas, num contexto de restrição dos orçamentos públicos, foi um dos fatores que impulsionaram as reformas nos sistemas de saúde. Como bem destacado por Médici (1995), a expansão horizontal e vertical da cobertura, a incorporação de inovações tecnológicas, a transição demográfica e a transição epidemiológica estão entre as principais causas responsáveis por esse crescimento.

Além dos limites impostos pela insuficiência de recursos, é necessário destacar que as reformas dos sistemas de saúde ocorreram em um momento de construção de uma determinada "agenda internacional para as políticas de saúde" (Mattos, 2001), formada pela oferta de ideias produzidas pelo conjunto de agências que integram a comunidade internacional de ajuda ao desenvolvimento, com destaque para o Banco Mundial e para a Organização Mundial da Saúde (OMS). Segundo

\footnotetext{
${ }^{10}$ Indicadores quantitativos: gasto social como \% do PIB; gasto social sobre o gasto público total; gasto social real per capita; e gasto social real por dependente.

${ }^{11}$ Indicadores qualitativos: mudança estrutural (composição do gasto); cortes em programas; e residualização dos welfare states.
} 
Mattos (2001), tanto o Banco Mundial como a OMS ensejaram, ao longo das décadas de 1980-90, apresentar um conjunto de recomendações e sugestões sobre as reformas dos sistemas de saúde e sobre as próprias atribuições dos governos no setor, mediante um considerável esforço de pesquisa conduzido por técnicos altamente especializados das duas agências.

Esse esforço de pesquisa procurou oferecer critérios para distinguir, entre as diversas experiências de reformas em curso, aquelas que seriam, na visão do Banco Mundial e da OMS, mais adequadas aos países em desenvolvimento, servindo como parâmetros para a alocação de recursos e privilegiando aqueles países alinhados com as recomendações propostas. Dessa forma, a oferta de ideias dessas duas agências cumpriu, de certa forma, o papel de disciplinar as políticas dos países em desenvolvimento, "quer pela força das ideias supostamente universais, quer pelo constrangimento indireto, análogo ao aplicado por vários agentes econômicos privados que atuam nos mercados financeiros internacionais" (Mattos, 2001: 388).

De modo geral, a resposta dos principais países à crise dos sistemas de saúde tem sido a adoção de mecanismos para ampliar o controle sobre os custos e a ênfase na utilização de métodos mais eficientes de gestão, aliados à tendência de separação entre o financiamento e a provisão de serviços, sem alterar, entretanto, a natureza pública da política de saúde. Segundo Dain (2000), as experiências dos países latino-americanos evidenciaram a adoção de diferentes alternativas de encaminhamento da questão. Assim, enquanto alguns países implementaram mudanças bruscas em seus sistemas de saúde, associadas à privatização dos serviços, outros mantiveram praticamente inalteradas suas políticas de saúde. Essa constatação é confirmada por dados levantados para 33 países da América Latina e Caribe de acordo com os quais os sistemas de saúde desses países apresentam grande heterogeneidade no que diz respeito aos níveis de gastos totais com saúde, incluindo a participação dos gastos governamentais e do setor privado no sistema (Nepp, 2003).

A análise do conjunto de reformas efetuadas pelos principais países da Europa e das Américas permite identificar duas importantes lições (Silva, 2003). A primeira lição seria a inexistência de uma tendência consolidada de financiamento e gestão dos sistemas de saúde, sendo impossível demonstrar a superioridade de modelos baseados exclusivamente nas regras de mercado ou, ao contrário, de modelos plenamente estatais. Dessa forma, o desafio anunciado desde a segunda metade da década de 1990 seria o de superar a velha dicotomia Estado versus mercado, mediante a adoção de novos instrumentos de política capazes de integrar adequadamente as capacidades pública e privada.

A segunda lição estaria relacionada com o fato de que as reformas dos sistemas de saúde teriam envolvido mudanças tanto no nível macro das políticas de saúde como no nível micro das organizações. No nível macro, realizaram-se modificações no sentido de propiciar maior contenção de custos e ampliar o processo de descentralização dos serviços para as esferas locais e regionais. No plano das organizações, procurou-se separar o financiamento da prestação de serviços, por meio da introdução de mecanismos de competição administrada, a fim de aumentar a eficiência dos serviços e sua resolutividade. A combinação desses dois níveis teria envolvido as modificações descritas a seguir. 


\section{Mudanças na Gestão Pública Brasileira e Reflexos na Política Social e de Saúde}

No Brasil, a mudança de orientação nas funções do Estado entrou para a agenda governamental e ganhou força a partir da década de 1990, com os processos de reforma administrativa e de privatização de empresas estatais. Entretanto, como bem destacado por Abrucio (2007), esse processo teve início com o fim do período militar, durante os anos 1980, num contexto de crise do regime autoritário e, sobretudo, da derrocada do modelo nacional-desenvolvimentista. Partia-se da constatação de que os militares haviam potencializado os problemas históricos da administração pública brasileira - descontrole financeiro, falta de responsabilização dos governantes e burocratas perante a sociedade, politização indevida da burocracia nos estados e municípios, além da fragmentação excessiva das empresas públicas, com a perda de foco de atuação governamental - e que, portanto, era necessário encontrar soluções que dessem conta do novo momento histórico.

Do ponto de vista da gestão pública, três conjuntos de mudanças foram introduzidos pela Constituição de 1988 no sentido de combater o legado deixado pelos militares: a democratização do Estado, por meio do fortalecimento do controle externo da administração pública e do reforço dos princípios da legalidade e da publicidade; a descentralização das políticas públicas, o que abriu oportunidades para maior participação social e para inovações no campo da gestão pública, levando em conta a realidade e as potencialidades locais; e a profissionalização da burocracia, mediante adoção do princípio da seleção meritocrática e universal, consubstanciada pelo concurso público. Entretanto, a implementação dessas mudanças ocasionou diversos problemas nas décadas seguintes, redundando no papel figurativo de muitos mecanismos de controle e de participação social (tribunais de contas e conselhos de políticas públicas), em relações intergovernamentais conflituosas e não cooperativas (federalismo compartimentalizado) e na persistência de um número elevado de cargos em comissão no funcionalismo público (Abrucio, 2007).

A modernização da gestão pública no Brasil foi fortemente influenciada por experiências e recomendações importadas de outros países e contextos. Como bem destacam Tenório e Saravia (2006), a publicação em português do livro de Osborne e Gaebler (1994) teria exercido grande influência por aqui, com a premissa de que o empreendedorismo é uma característica da iniciativa privada que deveria transformar a gestão pública. Governo empreendedor ou inovador seria aquele que emprega os recursos de modo a maximizar a produtividade e a eficiência. Alguns adjetivos utilizados permitem verificar a direção das recomendações: governo catalisador, pertencente à comunidade, competitivo, orientado por missões, de resultados, orientado ao cliente, empreendedor, preventivo, descentralizado, orientado para o mercado e reinventado.

Viana e Silva (2012) sugerem que as mudanças implementadas estão associadas a três períodos distintos, caracterizados por diferentes institucionalidades da política social no Brasil após a Constituição de 1988: uma institucionalidade neoliberal, durante os governos Collor (1990-1992), Franco (1992-1994) e Cardoso (1995-2002); uma institucionalidade de transição, durante o primeiro governo Lula (2003-2006); e a institucionalidade neodesenvolvimentista, a partir do segundo governo Lula (2007-2010). As características de cada período tendem a ser diferentes do ponto de vista político e 
econômico, assim como as interligações entre as políticas econômica e social, as estratégias-chave, o público-alvo, as formas e os agentes da provisão de serviços, e o tipo de financiamento desenhado para a política social e, em especial, para a política de saúde.

No período de institucionalidade neoliberal, a política social teve como estratégia-chave a descentralização, associada ao incentivo às parcerias público-privadas, ao estímulo ao controle social e à adoção de ações focalizadas em regiões e populações mais pobres. Já no último período (neodesenvolvimentista), as políticas com recortes territoriais (regionais, urbanas, metropolitanas) assumiram maior protagonismo, assim como maiores investimentos públicos em saneamento, habitação e saúde (federais e estaduais), mantendo-se o estímulo às parcerias público-privadas e a seletividade de programas direcionados para o combate à pobreza.

A política de saúde também pode ser diferenciada segundo esses mesmos períodos. A descentralização, acompanhada pela ênfase na atenção primária (via expansão da Estratégia Saúde da Família - ESF) principalmente para as regiões e populações mais pobres, constituiu o aspecto-chave da institucionalidade neoliberal. No período marcado pela institucionalidade neodesenvolvimentista, a regionalização assumiu maior centralidade, aliada à expansão do investimento público voltado para a ampliação de equipamentos de saúde (unidades de pronto atendimento), assim como para o estímulo ao fortalecimento do complexo econômico-industrial da saúde e do componente científico e tecnológico da política de saúde. Destaque deve ser dado para o papel crescente que as diversas organizações privadas (clínicas e hospitais privados, planos de saúde, organizações sociais etc.) passam a ter na oferta, no acesso e na gestão de serviços de saúde no país. No Quadro 2 sintetizam-se as principais características da política de saúde nos diferentes períodos.

Quadro 2 - Principais características da política de saúde no Brasil durante as diferentes institucionalidades

\begin{tabular}{|c|c|c|}
\hline $\begin{array}{c}\text { Neoliberal } \\
(1990-2002)\end{array}$ & $\begin{array}{c}\text { Transição } \\
(2003-2006)\end{array}$ & $\begin{array}{l}\text { Neodesenvolvimentista } \\
\text { (a partir de 2007) }\end{array}$ \\
\hline $\begin{array}{l}\text { - Reorganização institucional do } \\
\text { - Inovações (descentralização) } \\
\text { (PAB/CPMF/EC 29) } \\
\text { - Atenção básica e ESF } \\
\text { - Medicamentos genéricos } \\
\text { - Mutirões } \\
\text { - DST/Aids } \\
\text { - Agências reguladoras (Anvisa } \\
\text { - ANS) } \\
\text { - Organizações sociais de saúde }\end{array}$ & $\begin{array}{l}\text { - Expansão da ESF(Proesf) } \\
\text { - Saúde bucal (Brasil Sorridente) } \\
\text { - Humanização na saúde } \\
\text { - Nova forma de acesso a } \\
\text { medicamentos (Farmácia } \\
\text { Popular) } \\
\text { - Urgência e emergência: Samu/ } \\
\text { Centrais de Regulação } \\
\text { - Gestão do trabalho e da } \\
\text { educação em saúde } \\
\text { - Pacto pela Saúde }\end{array}$ & $\begin{array}{l}\text { - Complexo econômico-industrial } \\
\text { da saúde } \\
\text { - Gestão de tecnologias em saúde } \\
\text { - Fomento a pesquisas (editais } \\
\text { nacionais, PPSUS etc.) } \\
\text { - Hospitais filantrópicos de } \\
\text { excelência (Proadi-SUS) } \\
\text { - Nova proposta de regionalização } \\
\text { - Redes de atenção à saúde e } \\
\text { - linhas de cuidado } \\
\text { - MPA } 24 \text { horas } \\
\text { Mais Médicos }\end{array}$ \\
\hline
\end{tabular}

PAB, piso da atenção básica; CPMF, Contribuição Provisória sobre Movimentação Financeira; EC, emenda constitucional; Anvisa, Agência Nacional de Vigilância Sanitária; ANS, Agência Nacional de Saúde Suplementar; Proesf, Projeto de Expansão e Consolidação da Saúde da Família; Samu, Serviço de Atendimento Móvel de Urgência; PPSUS, Programa Pesquisa para o Sistema Único de Saúde; Proadi-SUS, Programa de Apoio ao Desenvolvimento Institucional do Sistema Único de Saúde; UPA, Unidade de Pronto Atendimento.

Fonte: adaptado de Viana e Silva (2012). 


\section{Análise Descritiva dos Segmentos Institucionais de Gestão em Saúde no Brasil (2005-2013)}

Considerada a diversidade de modalidades institucionais de gestão e prestação de serviços no setor Saúde no Brasil, é complexa a tarefa de definir ordenações e classificações que permitam tanto análises distintivas, como de agregados com características afins. No Brasil, o CNES estabelece uma tipologia com o detalhamento de 13 modalidades institucionais para o setor (definidas como "natureza da organização"), para as quais disponibiliza dados que podem ser processados por configurações e ordenações sistêmicas (níveis de hierarquia, esferas administrativas, tipos de estabelecimentos, personalidades jurídicas etc.), tipos de formalizações normativas (contratos, convênios, habilitações etc.), características de estruturas físicas (leitos hospitalares, equipamentos etc.) e quantitativos da produção de serviços (atendimentos prestados etc.) e da força de trabalho (notadamente ocupações profissionais). ${ }^{12}$

Os dados do CNES sobre os estabelecimentos de saúde estão disponíveis em série histórica de períodos mensais, iniciada em agosto de 2005, período ainda curto para análises de tendências retrospectivas que possam subsidiar projeções e análises prospectivas mais consistentes. Além disso, tal fonte secundária ainda apresenta indícios de subnotificações, que podem gerar vieses analíticos. Mesmo assim, trata-se da fonte disponível de maior confiabilidade, uma vez que a maior parte dos dados anteriores acessíveis provém de levantamentos amostrais periódicos (Pesquisa de Assistência Médico-Sanitária) realizados pelo IBGE.

Embora a classificação de estabelecimentos de saúde por naturezas administrativas adotada pelo CNES permita um maior detalhamento de tipos específicos, para análises mais abrangentes existem algumas classificações imprecisas (por exemplo, a classificação de organizações sociais como “administração indireta”). Considerando análises que levem em conta outras características, além da "natureza administrativa", há o requerimento de critérios de agregação, classificação e síntese.

Com o propósito específico de realizar análise descritiva e tendencial, simplificada e subsidiária para projeção de cenários futuros, optou-se por um escopo com agregação segmentar e classificação mais abrangente, com três setores primordiais de institucionalidades (pública estatal, pública não estatal e privada). Por meio dessa classificação inicial, considerados também os critérios de égide formal de direito administrativo (público ou privado) e relação com o SUS (serviços próprios, complementares ou suplementares), estabeleceu-se a derivação de nove segmentos institucionais, descritos a seguir (Quadro 3) e esquematizados na Figura 1.

\footnotetext{
${ }^{12}$ As modalidades de natureza organizativa estabelecidas pelo CNES são: administração direta da saúde (Ministério da Saúde, secretarias estaduais e Municipais de Saúde); administração direta de outros órgãos (Ministério da Educação, Forças Armadas etc.); administração indireta via autarquias; administração indireta via fundações públicas; administração indireta via empresas públicas; administração indireta via organizações sociais públicas; empresas privadas; fundações privadas; cooperativas; serviços sociais autônomos; entidades beneficentes sem fins lucrativos; sociedades de economia mista; e sindicatos.
} 
Quadro 3 - Tipos de esferas, setores e segmentos institucionais utilizados para a análise de tendências e cenários futuros

A) Esfera pública, setor estatal.

A1) Segmento de administração direta, égide de direito público, serviços próprios do SUS: serviços próprios do Ministério da Saúde, secretarias estaduais e municipais de Saúde.

A2) Segmento de administração direta, outros órgãos estatais (exceto do setor Saúde), égide de direito público, serviços complementares ao SUS e suplementares: serviços de outros ministérios, como o Ministério da Educação (por exemplo, alguns hospitais universitários), serviços de Forças Armadas etc.

A3) Segmento de administração indireta, égide de direito público, serviços próprios do SUS: serviços de autarquias (federais, estaduais e municipais), autarquias em regime especial, fundações públicas, consórcios interfederativos etc.

A4) Segmento de administração indireta, égide de direito privado, serviços próprios do SUS: serviços de empresas públicas de saúde (alguns hospitais universitários, serviços estaduais, municipais etc.), fundações estatais, autarquias em regime especial, sociedades de economia mista, parcerias públicoprivadas.

A5) Segmento de previdência complementar de servidores de estatais, sob administração indireta, égide de direito privado, serviços suplementares ao SUS: serviços de entidades fechadas de previdência complementar (EFPC) de servidores públicos (federais, estaduais e municipais) e de servidores de empresas estatais etc. Alguns dos serviços de saúde de fundos de previdência de servidores de estatais estão cadastrados no CNES como fundações privadas sem fins lucrativos (Cassi, Petros etc.).

B) Esfera pública, setor não estatal: segmento de serviços públicos ofertados por associações civis sem fins lucrativos, égide de direito privado, com serviços complementares contratados pelo SUS e serviços suplementares: associações civis qualificadas como organizações sociais (OSs), organizações da sociedade civil de interesse público (Oscips) e congêneres.

Esfera privada, setor privado:

C) Segmento privado sem fins lucrativos, égide de direito privado, com serviços complementares conveniados ao SUS e serviços suplementares: entidades beneficentes, serviços sociais autônomos, associações sindicais, fundações privadas (incluídas algumas entidades fechadas de previdência complementar de servidores de estatais), cooperativas etc.

D) Segmento privado com fins lucrativos, égide de direito privado, com serviços complementares contratados pelo SUS e serviços suplementares: serviços de empresas privadas (várias modalidades).

E) Segmento misto e ambivalente (público-privado), égide de direito privado, com serviços complementares contratados pelo SUS e serviços suplementares: sociedades de economia mista, contratos de parcerias público-privadas e congêneres. 
Figura 1 - Representação esquemática de setores, segmentos e modalidades de serviços de saúde no Brasil

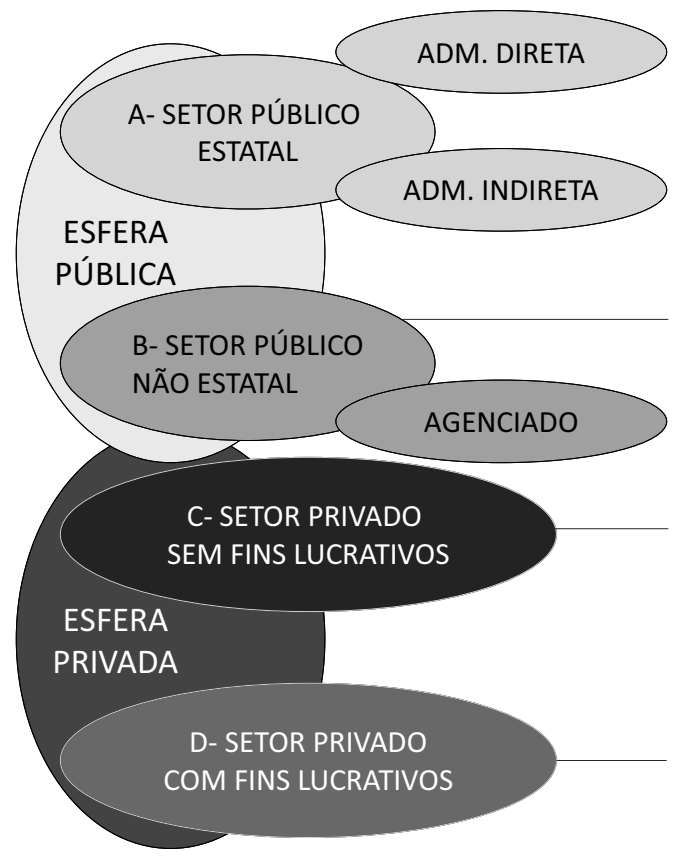

A1. Serviços governamentais próprios

A2. Serviços estatais de outros setores (exceto de Saúde)

A3. Autarquias típicas e sob regime especial de direito público

A4. Autarquias típicas e sob regime especial de direito privado

A5. Fundações privadas previdenciárias das Estatais

B. Organizações sociais e congêneres

C. Estabelecimentos fundacionais, sindicais, cooperativados, associativos filantrópicos etc.

\section{Empresas privadas}

E. Estabelecimentos mistos e ambivalente: economia mista

Essa classificação permite um melhor discernimento da ênfase em agregados com características afins, com pelo menos três setores (estatal, público-estatal e privado) e foco naqueles segmentos em que há disponibilidade de agregação de dados e melhor possibilidade para análises comparativas. Com base nessa classificação, buscou-se uma análise mais descritiva e sumária do atual cenário de institucionalidades de gestão em saúde, em termos de quantificação de proporcionalidades para estabelecimentos cadastrados (CNES) e agregados em segmentos institucionais. Em tal descrição, realçam-se aspectos relevantes da oferta e organização desses serviços (tipos, níveis de atenção, distribuição estadual, vínculos empregatícios de trabalhadores etc.).

A forma de agregação de dados do CNES para a conformação de segmentos institucionais está descrita no Quadro 4 a seguir: 
Quadro 4 - Forma de agregação de dados com base nas naturezas administrativas de estabelecimentos de saúde definidas no CNES para segmentos institucionais de gestão em saúde

\begin{tabular}{|c|c|}
\hline Natureza administrativa (CNES) & Segmentos institucionais de gestão em Saúde \\
\hline 1. Administração direta da Saúde & A1. Estatal, administração direta, setor Saúde \\
\hline 2. Administração direta de outros órgãos & A2. Estatal, administração direta, outros órgãos \\
\hline 3. Administração indireta, autarquias & \multirow{2}{*}{ A3. Estatal administração indireta, direito público } \\
\hline 4. Administração indireta, fundações públicas & \\
\hline 5. Administração indireta, empresas públicas & A4. Estatal administração indireta, direito privado \\
\hline $\begin{array}{l}\text { 6. Administração indireta, organizações sociais } \\
\text { públicas }\end{array}$ & $\begin{array}{l}\text { B. Associações civis sem fins lucrativos qualificadas } \\
\text { como organizações sociais de saúde }\end{array}$ \\
\hline 7. Empresas privadas & C. Privado com fins lucrativos \\
\hline 8. Fundações privadas & \multirow{5}{*}{ D. Privado sem fins lucrativos } \\
\hline 9. Cooperativas & \\
\hline 10. Serviços sociais autônomos & \\
\hline 11. Entidades beneficentes sem fins lucrativos & \\
\hline 12. Sindicatos & \\
\hline 13. Sociedades de economia mista & E. Misto \\
\hline
\end{tabular}

Em ambas as configurações (tipologia CNES e de segmentos institucionais) não foi possível a discriminação e agregação específica de estabelecimentos de saúde do segmento de "Previdência complementar de servidores de estatais (A5)", uma vez que estão cadastrados (CNES) de forma dispersa em várias modalidades de natureza administrativa.

Para a projeção parcial de tendência e cenário futuro, optou-se por uma análise retrospectiva de variações quantitativas de dados acerca de determinadas características dos estabelecimentos de saúde, ordenados em segmentos institucionais, tomando-se como referências temporais os meses de dezembro de 2005 e 2013. Portanto, não se trata propriamente de enfoque longitudinal, mas de enfoque em dois recortes transversais com intercurso de oito anos. Assim, com base na análise de algumas tendências retrospectivas, definidas por variações entre os dois períodos aludidos, busca-se a projeção de uma tendência inercial para o futuro, ou seja, aquela em que estariam mantidos os principais fatores determinantes e condicionantes do período considerado retrospectivamente. ${ }^{13}$

\footnotetext{
${ }^{13}$ Conforme referido anteriormente, uma análise retrospectiva entre séries históricas transversais de somente oito anos não permite projeções mais consistentes para longo prazo; todavia, é esse o período em que os dados estão disponíveis.
} 


\section{Descrição da Trajetória Tendencial dos Segmentos Institucionais de Gestão em Saúde no Período 2005-2013}

As informações descritas e ordenadas no Quadro 5 por modalidades de segmentos institucionais de gestão em saúde apresentam as variações proporcionais nos períodos referidos acerca dos seguintes aspectos: quantidade de estabelecimentos, proporção de estabelecimentos com vínculo de complementaridade com o SUS, principais tipos de estabelecimentos, disponibilidade de leitos hospitalares para o SUS, variações por níveis de complexidade assistencial, distribuição de taxas de oferta por estados brasileiros, disponibilização de atividades de ensino e caracterização de vínculos empregatícios de servidores (somente para 2013). 


\begin{tabular}{|c|c|c|c|c|c|c|c|c|}
\hline \multirow{2}{*}{ Item } & \multicolumn{4}{|c|}{ Público-estatal } & \multirow{2}{*}{$\begin{array}{c}\text { Associações } \\
\text { civis sem fins } \\
\text { lucrativos } \\
\text { B }\end{array}$} & \multicolumn{3}{|c|}{ Privado } \\
\hline & A1 & $\mathrm{A} 2$ & A3 & A4 & & $\mathrm{C}$ & D & $\mathrm{E}$ \\
\hline $\begin{array}{l}\text { Número de } \\
\text { estabelecimentos } \\
\text { e taxa média de } \\
\text { incremento }\end{array}$ & $\begin{array}{l}\text { De } 42,2 \% \text { do } \\
\text { total em } 2005 \\
\text { para } 27,1 \% \text { em } \\
2013 . \text { Aumento } \\
\text { de } 41,4 \% \text { no } \\
\text { período. }\end{array}$ & $\begin{array}{l}\text { De } 0,3 \% \text { do } \\
\text { total em } 2005 \\
\text { para } 0,2 \% \text { em } \\
2013 . \text { Aumento } \\
\text { de } 52 \% \text { no } \\
\text { período. }\end{array}$ & $\begin{array}{l}\text { De } 0,5 \% \text { do } \\
\text { total em } 2005 \\
\text { para } 0,3 \% \text { em } \\
2013 . \text { Aumento } \\
\text { de } 48,3 \% \text { no } \\
\text { período. }\end{array}$ & $\begin{array}{l}\text { De } 0,1 \% \text { do } \\
\text { total em } 2005 \\
\text { para } 0,2 \% \text { em } \\
2013 . \text { Aumento } \\
\text { de } 302 \% \text { no } \\
\text { período. }\end{array}$ & $\begin{array}{l}\text { Cerca de } 0,1 \% \\
\text { do total em } \\
2005 \text { e } 2013 \text {. } \\
\text { Aumento } \\
\text { de } 240 \% \text { no } \\
\text { período. }\end{array}$ & $\begin{array}{l}\text { De } 4,3 \% \text { do total } \\
\text { em } 2005 \text { para } \\
3,4 \% \text { em } 2013 \text {. } \\
\text { Aumento de } 75 \% \\
\text { no período. } \\
\text { Pessoa física: } 1 / 3 \\
\text { do total. }\end{array}$ & $\begin{array}{l}\text { De } 52,5 \% \text { do } \\
\text { total em } 2005 \\
\text { para } 68,6 \% \text { em } \\
2013 . \text { Aumento } \\
\text { de } 188 \% \text { no } \\
\text { período. } \\
\text { Pessoa física: } \\
\text { de } 47,7 \% \text { para } \\
52,7 \% \text {. }\end{array}$ & $\begin{array}{l}\text { - De } 0,05 \% \text { do } \\
\text { total em } 2005 \\
\text { para } 0,01 \% \text { em } \\
2013 . \text { Aumento } \\
\text { de } 2.144 \% \text { no } \\
\text { período. } \\
\text { - } 100 \% \text { pessoas } \\
\text { jurídicas (PJ) para } \\
2005 \text { e } 2013 \text {. }\end{array}$ \\
\hline $\begin{array}{l}\text { Proporção de } \\
\text { estabelecimentos } \\
\text { com vínculo de } \\
\text { complementaridade } \\
\text { com o SUS }\end{array}$ & $\begin{array}{l}\text { De } 99,4 \% \text { em } \\
2005 \text { para } \\
99,6 \% \text { em } \\
2013 .\end{array}$ & $\begin{array}{l}\text { De } 88,4 \% \text { em } \\
2005 \text { para } \\
85,9 \% \text { em } \\
2013 .\end{array}$ & $\begin{array}{l}\text { De } 97,7 \% \text { em } \\
2005 \text { para } \\
94,5 \% \text { em } \\
2013 .\end{array}$ & $\begin{array}{l}\text { De } 96,2 \% \text { em } \\
2005 \text { para } 97,7 \% \\
\text { em } 2013 \text {. }\end{array}$ & $\begin{array}{l}\text { De } 96,8 \% \text { em } \\
2005 \text { para } \\
94,4 \% \text { em } 2013 .\end{array}$ & $\begin{array}{l}\text { De } 60 \% \text { em } 2005 \\
\text { para } 40 \% \text { em } \\
2013 . \\
\text { Somente PJ: de } \\
99 \% \text { para } 71 \% .\end{array}$ & $\begin{array}{l}\text { De } 14,6 \% \text { em } \\
2005 \text { para } 6,5 \% \\
\text { em } 2013 . \\
\text { Somente PJ: } \\
\text { de } 86,7 \% \text { para } \\
47,1 \% \text {. }\end{array}$ & $\begin{array}{l}\text { - De } 44,4 \% \text { em } \\
2005 \text { para } 3,6 \% \\
\text { em } 2013 . \\
\text { - Somente PJ: de } \\
\text { 100\% para 50,8\%. }\end{array}$ \\
\hline $\begin{array}{l}\text { Principais tipos de } \\
\text { estabelecimentos }\end{array}$ & $\begin{array}{l}\text { Ambulatórios } \\
\text { de atenção } \\
\text { básica, } \\
\text { unidades de } \\
\text { vigilância em } \\
\text { saúde, hospitais } \\
\text { gerais, Centros } \\
\text { de Atenção } \\
\text { Psicossocial e } \\
\text { laboratórios } \\
\text { públicos. }\end{array}$ & $\begin{array}{l}\text { Centros } \\
\text { de saúde, } \\
\text { hospitais gerais } \\
\text { (notadamente } \\
\text { hospitais } \\
\text { universitários) } \\
\text { e consultórios } \\
\text { isolados. }\end{array}$ & $\begin{array}{l}\text { Centros } \\
\text { de saúde, } \\
\text { hospitais } \\
\text { gerais, } \\
\text { unidades } \\
\text { móveis de } \\
\text { atendimento } \\
\text { pré-hospitalar } \\
\text { de urgência } \\
\text { e centros de } \\
\text { especialidades } \\
\text { médicas. }\end{array}$ & $\begin{array}{l}\text { Centros de } \\
\text { saúde, unidades } \\
\text { móveis de } \\
\text { atendimento } \\
\text { pré-hospitalar de } \\
\text { urgência, centros } \\
\text { de especialidades } \\
\text { médicas e } \\
\text { serviços de apoio } \\
\text { diagnóstico e } \\
\text { terapêutico. }\end{array}$ & $\begin{array}{l}\text { Unidades de } \\
\text { urgência e } \\
\text { emergência } \\
\text { e centros } \\
\text { de atenção } \\
\text { hemoterápica. }\end{array}$ & $\begin{array}{l}\text { - Complementar: } \\
\text { hospitais gerais, } \\
\text { hospitais } \\
\text { especializados, } \\
\text { unidades mistas e } \\
\text { centros de parto } \\
\text { normal. } \\
\text { - Suplementar: } \\
\text { consultórios } \\
\text { isolados e } \\
\text { policlínicas }\end{array}$ & $\begin{array}{l}\text { - Complementar: } \\
\text { hospitais gerais, } \\
\text { hospitais } \\
\text { especializados } \\
\text { e unidades } \\
\text { de apoio em } \\
\text { diagnose e } \\
\text { terapia. } \\
\text { - Suplementar: } \\
\text { consultórios } \\
\text { isolados, centros } \\
\text { de especialidades } \\
\text { médicas, } \\
\text { policlínicas } \\
\text { e pronto } \\
\text { atendimento }\end{array}$ & \\
\hline $\begin{array}{l}\text { Serviços hospitalares: } \\
\text { disponibilidade de } \\
\text { leitos para o SUS }\end{array}$ & $\begin{array}{l}\text { 98\% dos leitos } \\
\text { disponíveis } \\
\text { ao SUS no } \\
\text { período. }\end{array}$ & $\begin{array}{l}\text { De } 83,5 \% \\
\text { dos leitos } \\
\text { disponíveis ao } \\
\text { SUS em } 2005 \\
\text { para } 61,5 \% \text { em } \\
2013 .\end{array}$ & $\begin{array}{l}\text { Cerca de } \\
95 \% \text { de leitos } \\
\text { disponíveis } \\
\text { ao SUS no } \\
\text { período. }\end{array}$ & $\begin{array}{l}\text { Cerca de } 92 \% \text { de } \\
\text { leitos disponíveis } \\
\text { ao SUS no } \\
\text { período. }\end{array}$ & $\begin{array}{l}\text { De } 99 \% \text { de leitos } \\
\text { disponíveis ao } \\
\text { SUS em } 2005 \\
\text { para } 96,5 \% \text { em } \\
2013 .\end{array}$ & $\begin{array}{l}\text { De } 75 \% \text { de leitos } \\
\text { disponíveis ao } \\
\text { SUS em } 2005 \text { para } \\
70 \% \text { em } 2013 \text {. }\end{array}$ & $\begin{array}{l}\text { De } 56,5 \% \text { de } \\
\text { leitos disponíveis } \\
\text { ao SUS em } 2005 \\
\text { para } 36 \% \text { em } \\
2013 .\end{array}$ & $\begin{array}{l}\text { De } 100 \% \text { em } 2005 \\
\text { para } 43 \% \text { em } \\
2013 .\end{array}$ \\
\hline
\end{tabular}


Quadro 5 - Caracterização dos segmentos institucionais de gestão em saúde com base em análise tendencial retrospectiva. Brasil 2005-2013 (cont.)

\begin{tabular}{|c|c|c|c|c|c|c|c|c|}
\hline \multirow{2}{*}{ Item } & \multicolumn{4}{|c|}{ Público-estatal } & \multirow{2}{*}{$\begin{array}{c}\text { Associações } \\
\text { civis sem fins } \\
\text { lucrativos } \\
\text { B }\end{array}$} & \multicolumn{3}{|c|}{ Privado } \\
\hline & A1 & A2 & A3 & A4 & & $\mathrm{C}$ & $\mathrm{D}$ & $\mathrm{E}$ \\
\hline $\begin{array}{l}\text { Proporção de } \\
\text { estabelecimentos que } \\
\text { mantêm vínculos com } \\
\text { o SUS sob gestão } \\
\text { municipal, estadual, } \\
\text { gestão dupla e outras } \\
\text { formas de gestão } \\
\text { (informados) }\end{array}$ & $\begin{array}{l}\text { Municipal: de } \\
71 \% \text { em } 2005 \\
\text { para } 89 \% \text { em } \\
2013 . \\
\text { Estadual: de } \\
3,5 \% \text { em } 2005 \\
\text { para 3,7\% em } \\
2013 . \\
\text { Dupla e outras } \\
\text { formas: de } \\
24,2 \% \text { em } 2005 \\
\text { para } 7,2 \% \text { em } \\
2013 .\end{array}$ & $\begin{array}{l}\text { Municipal: de } \\
67,3 \% \text { em } 2005 \\
\text { para } 72,2 \% \text { em } \\
2013 . \\
\text { Estadual: de } \\
\text { 12,2\% em } 2005 \\
\text { para 18,8\% em } \\
2013 . \\
\text { Dupla e outras } \\
\text { formas: de } \\
\text { 19,9\% em } 2005 \\
\text { para } 9 \% \text { em } \\
2013 .\end{array}$ & $\begin{array}{l}\text { Municipal: } \\
\text { de } 68,2 \% \text { em } \\
2003 \text { para } \\
75,2 \% \text { em } \\
2013 . \\
\text { Estadual: de } \\
\text { 11\% em } 2005 \\
\text { para 16,3\% em } \\
2013 . \\
\text { Dupla e outras } \\
\text { formas: de } \\
\text { 20,4\% em } \\
\text { 2005 para } \\
\text { 8,5\% em } 2013 .\end{array}$ & $\begin{array}{l}\text { Municipal: de } \\
69 \% \text { em } 2003 \\
\text { para } 79,4 \% \text { em } \\
2013 . \\
\text { Estadual: de } \\
\text { 10,4\% em } 2005 \\
\text { para } 12,2 \% \text { em } \\
2013 . \\
\text { Dupla e outras } \\
\text { formas: de } 19 \% \\
\text { em } 2005 \text { para } \\
8,4 \% \text { em } 2013 .\end{array}$ & $\begin{array}{l}\text { Municipal: de } \\
62 \% \text { em } 2003 \\
\text { para 54,4\% em } \\
2013 . \\
\text { Estadual: de } \\
6,3 \% \text { em } 2005 \\
\text { para 40,5\% em } \\
2013 . \\
\text { Dupla e outras } \\
\text { formas: de } \\
30,2 \% \text { em } 2005 \\
\text { para 5,1\% em } \\
2013\end{array}$ & $\begin{array}{l}\text { Municipal: de } 56 \% \\
\text { em } 2003 \text { para } \\
78,2 \% \text { em } 2013 . \\
\text { Estadual: de } \\
\text { 17,4\% em } 2005 \\
\text { para } 13,2 \% \text { em } \\
2013 . \\
\text { Dupla e outras } \\
\text { formas: de } 25 \% \\
\text { em } 2005 \text { para } \\
\text { 8,6\% em } 2013 \text {. }\end{array}$ & $\begin{array}{l}\text { Municipal: de } \\
\text { 44,4\% em } 2003 \\
\text { para } 91,8 \% \text { em } \\
2013 . \\
\text { Estadual: de } \\
\text { 44,4\% em } 2005 \\
\text { para 5,7\% em } \\
2013 . \\
\text { Dupla e outras } \\
\text { formas: de } 11,1 \% \\
\text { em } 2005 \text { para } \\
0,5 \% \text { em } 2013 .\end{array}$ & $\begin{array}{l}\text { Municipal: de } 73 \% \\
\text { em } 2003 \text { para } \\
90,4 \% \text { em } 2013 \text {. } \\
\text { Estadual: de } 10,6 \% \\
\text { em } 2005 \text { para } \\
6,2 \% \text { em } 2013 \text {. } \\
\text { Dupla e outras } \\
\text { formas: de } 14,8 \% \\
\text { em } 2005 \text { para } \\
3,3 \% \text { em } 2013 \text {. }\end{array}$ \\
\hline $\begin{array}{l}\text { Variações por níveis } \\
\text { de complexidade } \\
\text { assistencial } \\
\text { (informados) }\end{array}$ & $\begin{array}{l}\text { Atenção } \\
\text { básica: de } \\
\text { 51,3\% (2005) } \\
\text { para 42,8\% } \\
\text { (2013). } \\
\text { Média } \\
\text { complexidade } \\
\text { (MC): de } \\
\text { 44,3\% (2005) } \\
\text { para 43,4\% } \\
\text { (2013). } \\
\text { Alta } \\
\text { complexidade } \\
\text { (AC): de 4,3\% } \\
\text { (2005) para } \\
\text { 5,9\% (2013). }\end{array}$ & $\begin{array}{l}\text { A. básica: de } \\
\text { 46,4\% (2005) } \\
\text { para 43,2\% } \\
\text { (2013). } \\
\text { MC: de 40,8\% } \\
\text { (2005) para } \\
\text { 43,6\% (2013). } \\
\text { AC: de 12,8\% } \\
\text { (2005) para } \\
\text { 8,4\% (2013). }\end{array}$ & $\begin{array}{l}\text { A. básica: de } \\
14,6 \%(2005) \\
\text { para } 15,8 \% \\
(2013) . \\
\text { MC: de } \\
54,8 \%(2005) \\
\text { para } 55,2 \% \\
(2013) . \\
\text { AC: de } 30,5 \% \\
(2005) \\
\text { para } 26,4 \% \\
(2013) .\end{array}$ & $\begin{array}{l}\text { A. básica: de } \\
45,1 \%(2005) \\
\text { para } 22,7 \% \\
(2013) . \\
\text { MC: de 43,1\% } \\
\text { (2005) para } \\
58 \%(2013) . \\
\text { AC: de } 11,8 \% \\
\text { (2005) para } \\
8,6 \%(2013) .\end{array}$ & $\begin{array}{l}\text { A. Básica: de } \\
\text { 39,3\% (2005) } \\
\text { para 15,8\% } \\
\text { (2013). } \\
\text { MC: de 36,1\% } \\
\text { (2005) para } \\
\text { 59,1\% (2013). } \\
\text { AC: de 24,6\% } \\
\text { (2005) para } \\
21,2 \%(2013) .\end{array}$ & $\begin{array}{l}\text { A. Básica: de } \\
\text { 12,5\% (2005) } \\
\text { para 5\% (2013). } \\
\text { MC: de 61,8\% } \\
\text { (2005) para } \\
\text { 60,6\% (2013) } \\
\text { AC: de 24,2\% } \\
\text { (2005) para } \\
\text { 31,4\% (2013). }\end{array}$ & $\begin{array}{l}\text { A. Básica: de } \\
7,2 \%(2005) \\
\text { para } 2,9 \% \\
(2013) . \\
\text { MC: de } 67,2 \% \\
\text { (2005) para } \\
73,6 \%(2013) . \\
\text { AC: de } 25,6 \% \\
(2005) \text { para } \\
22,8 \%(2013) .\end{array}$ & $\begin{array}{l}\text { A. Básica: de } \\
\text { 0\% (2005) para } \\
\text { 14,4\% (2013). } \\
\text { MC: de } 50 \% \\
\text { (2005) para } \\
\text { 71,4\% (2013) } \\
\text { AC: de } 50 \% \\
\text { (2005) para } \\
\text { 14,3\% (2013). }\end{array}$ \\
\hline $\begin{array}{l}\text { Distribuição } \\
\text { geográfica das } \\
\text { taxas de oferta por } \\
10.000 \text { habitantes* }\end{array}$ & $\begin{array}{l}\text { Média } \\
\text { nacional: de } \\
2,8(2005) \\
\text { para } 3,6 \\
\text { (2013). } \\
\text { Maiores taxas } \\
\text { nos estados de } \\
\text { RR, PI e PB. }\end{array}$ & $\begin{array}{l}\text { Média } \\
\text { nacional: de } \\
\text { 1,7 (2005) } \\
\text { para 2,2 } \\
\text { (2013). } \\
\text { Maiores taxas } \\
\text { nos estados de } \\
\text { RR, AC, MA e } \\
\text { MG. }\end{array}$ & $\begin{array}{l}\text { Média } \\
\text { nacional: de } \\
3,0(2005) \\
\text { para 4,1 } \\
(2013) . \\
\text { Maiores taxas } \\
\text { nos estados } \\
\text { de PR, MG, PI } \\
\text { e SE. }\end{array}$ & $\begin{array}{l}\text { Média nacional: } \\
\text { de } 5,5 \text { (2005) } \\
\text { para } 21,1 \\
(2013) \text {. } \\
\text { Maiores taxas } \\
\text { nos estados de } \\
\text { RN, RR e MT. }\end{array}$ & $\begin{array}{l}\text { Média } \\
\text { nacional: de } \\
5,5(2005) \\
\text { para 10,2 } \\
(2013) . \\
\text { Maiores taxas } \\
\text { nos estados de } \\
\text { MS, MG, SC, } \\
\text { BA, MT, e RR. }\end{array}$ & $\begin{array}{l}\text { Média nacional: } \\
\text { de 2,8 (2005) } \\
\text { para 4,5 (2013). } \\
\text { Maiores taxas } \\
\text { nos estados de } \\
\text { SC, DF, MG, PR } \\
\text { e RS. }\end{array}$ & $\begin{array}{l}\text { Média nacional: } \\
\text { de 3,4 (2005) } \\
\text { para 9,1 (2013). } \\
\text { Maiores taxas } \\
\text { nos estados de } \\
\text { RS, SC, PR, DF, } \\
\text { SP, MG, ES, MS } \\
\text { e MT. }\end{array}$ & $\begin{array}{l}\text { Média nacional } \\
\text { de taxa de } \\
\text { cobertura de } \\
\text { planos de saúde: } \\
25 \% \text { em } 2013 . \\
\text { Maiores taxas nos } \\
\text { estados de SP, DF, } \\
\text { RJ, ES, MG, PR, } \\
\text { SC e RS. }\end{array}$ \\
\hline
\end{tabular}


Quadro 5 - Caracterização dos segmentos institucionais de gestão em saúde com base em análise tendencial retrospectiva. Brasil 2005-2013 (cont.)

\begin{tabular}{|c|c|c|c|c|c|c|c|c|}
\hline \multirow{2}{*}{ Item } & \multicolumn{4}{|c|}{ Público-estatal } & \multirow{2}{*}{$\begin{array}{l}\text { Associações } \\
\text { civis sem fins } \\
\text { lucrativos } \\
\text { B }\end{array}$} & \multicolumn{3}{|c|}{ Privado } \\
\hline & A1 & A2 & A3 & A4 & & C & D & $\mathrm{E}$ \\
\hline $\begin{array}{l}\text { Disponibilização de } \\
\text { atividades de ensino }\end{array}$ & $\begin{array}{l}\text { Cerca de } 2 \% \text { do } \\
\text { total em } 2005 \text { e } \\
2013 .\end{array}$ & $\begin{array}{l}\text { De } 17 \% \text { do } \\
\text { total em } 2005 \\
\text { para } 12 \% \text { em } \\
2013 .\end{array}$ & $\begin{array}{l}\text { De } 25 \% \text { do } \\
\text { total em } 2005 \\
\text { para } 20 \% \text { em } \\
2013 .\end{array}$ & $\begin{array}{l}\text { De } 9 \% \text { do total } \\
\text { em } 2005 \text { para } \\
3 \% \text { em } 2013 .\end{array}$ & $\begin{array}{l}\text { De } 11 \% \text { do total } \\
\text { em } 2005 \text { para } \\
6 \% \text { em } 2013 .\end{array}$ & $\begin{array}{l}\text { De } 11 \% \text { do total } \\
\text { em } 2005 \text { para } 6 \% \\
\text { em } 2013 .\end{array}$ & $\begin{array}{l}\text { Cerca de } 0,5 \% \text { do } \\
\text { total em } 2005 \text { e } \\
2013 .\end{array}$ & $\begin{array}{l}\text { De } 0 \% \text { em } 2005 \\
\text { para } 1 \% \text { em } 2013 .\end{array}$ \\
\hline $\begin{array}{l}\text { Caracterização } \\
\text { de vínculos } \\
\text { empregatícios dos } \\
\text { profissionais em } 2013\end{array}$ & $\begin{array}{l}\text { Estatutários: } \\
40,9 \% \\
\text { Temporários: } \\
25,5 \% \\
\text { CLT: } 13,7 \% \\
\text { Autônomos: } \\
\text { 10,4\% } \\
\text { Comissionados: } \\
\text { 1,2\% } \\
\text { Cooperativados: } \\
\text { 0,7\% } \\
\text { Contratos } \\
\text { verbais ou } \\
\text { informais: } 0,5 \% \\
\text { Outros } \\
\text { subtipos:1,1\% } \\
\text { S/I: } 6 \%\end{array}$ & $\begin{array}{l}\text { Estatutários: } \\
\text { 42,7\% } \\
\text { Temporários: } \\
8,6 \% \\
\text { CLT: 7,8\% } \\
\text { Autônomos: } \\
8,9 \% \\
\text { Comissionados: } \\
\text { 0,2\% } \\
\text { Cooperativados: } \\
\text { 0,4\% } \\
\text { Contratos } \\
\text { verbais ou } \\
\text { informais: } 0,8 \% \\
\text { Outros } \\
\text { subtipos:12,8\% } \\
\text { S/I: } 17,8 \%\end{array}$ & $\begin{array}{l}\text { Estatutários: } \\
35,7 \% \\
\text { Temporários: } \\
12 \% \\
\text { CLT: } 24,5 \% \\
\text { Autônomos: } \\
\text { 9,9\% } \\
\text { Comissiona- } \\
\text { dos: 0,7\% } \\
\text { Cooperativa- } \\
\text { dos: 0,4\% } \\
\text { Contratos } \\
\text { verbais ou } \\
\text { informais: } \\
\text { 0,5\% } \\
\text { Outros } \\
\text { subtipos: } \\
\text { 8,3\% } \\
\text { S/I: 8\% }\end{array}$ & $\begin{array}{l}\text { Estatutários: } \\
18 \% \\
\text { Temporários: } \\
\text { 18,7\% } \\
\text { CLT: } 26,5 \% \\
\text { Autônomos: } 7 \% \\
\text { Comissionados: } \\
\text { 0,9\% } \\
\text { Cooperativados: } \\
\text { 0,5\% } \\
\text { Contratos verbais } \\
\text { ou informais: } \\
\text { 0,6\% } \\
\text { Outros } \\
\text { subtipos:3,2\% } \\
\text { S/I: } 18,3 \%\end{array}$ & $\begin{array}{l}\text { Estatutários: } 0 \% \\
\text { Temporários: } \\
\text { 50,1\% } \\
\text { CLT: } 11,2 \% \\
\text { Autônomos: } \\
30 \% \\
\text { Comissionados: } \\
0 \% \\
\text { Cooperativados: } \\
\text { 0,3\% } \\
\text { Contratos } \\
\text { verbais ou } \\
\text { informais: } 0,1 \% \\
\text { Outros } \\
\text { subtipos: } 2,2 \% \\
\text { S/I: } 5 \%\end{array}$ & $\begin{array}{l}\text { Estatutários: 0\% } \\
\text { Temporários: } \\
\text { 5,2\% } \\
\text { CLT: 42,2\% } \\
\text { Autônomos: 36\% } \\
\text { Comissionados: } \\
0 \% \\
\text { Cooperativados: } \\
\text { 5,7\% } \\
\text { Contratos verbais } \\
\text { ou informais: } \\
\text { 1,3\% } \\
\text { Outros } \\
\text { subtipos: } 2,6 \% \\
\text { S/I: } 7 \%\end{array}$ & $\begin{array}{l}\text { Estatutários: 0\% } \\
\text { Temporários: } \\
6,4 \% \\
\text { CLT: } 22 \% \\
\text { Autônomos: 49\% } \\
\text { Comissionados: } \\
\text { 0\% } \\
\text { Cooperativados: } \\
\text { 0,6\% } \\
\text { Contratos verbais } \\
\text { ou informais: } \\
\text { 1,7\% } \\
\text { Outros } \\
\text { subtipos:11,2\% } \\
\text { S/I: 9,1\% }\end{array}$ & $\begin{array}{l}\text { Estatutários: } 0 \% \\
\text { Temporários: } 10 \% \\
\text { CLT: } 34 \% \\
\text { Autônomos: 36\% } \\
\text { Comissionados: 0\% } \\
\text { Cooperativados: } \\
\text { 0,6\% } \\
\text { Contratos verbais } \\
\text { ou informais: } 2,2 \% \\
\text { Outros } \\
\text { subtipos:12,5\% } \\
\text { S/I: 4,7\% }\end{array}$ \\
\hline
\end{tabular}

Fonte: Elaboração própria, com base em dados do DataSUS e CNES, 2013.

(*) Mapas em anexo

Legenda:

A1 - estatal, administração direta, setor governamental de Saúde

A2 - estatal, administração direta, outros órgãos

B - associações civis sem fins lucrativos

A3 - estatal, administração indireta, direito público

$\mathrm{C}$ - privado sem fins lucrativos

A4 - estatal, administração indireta, direito privado

D - privado com fins lucrativos

E - privado misto 
Por meio das informações do Quadro 5, é possível constatar que:

- Os tipos de estabelecimentos de saúde que predominam em cada segmento são diferentes. Na esfera pública estatal há predomínio de ambulatórios de atenção básica, unidades de vigilância em saúde, centros de atenção psicossocial, laboratórios públicos, hospitais gerais, centros de saúde, unidades móveis pré-hospitalares e centros de especialidades médicas. Na esfera privada o destaque é para os serviços de atenção hospitalar geral e especializada (complementar ao SUS) e para os consultórios isolados, policlínicas e centros de especialidades (na saúde suplementar).

- Houve aumento absoluto no número de estabelecimentos cadastrados no CNES em todos os segmentos, mas esse aumento foi bastante desigual. Como resultado, a proporção de estabelecimentos públicos em relação ao total caiu, principalmente os serviços de saúde da administração direta. De modo inverso, a proporção de estabelecimentos do setor privado aumentou no período, com destaque para aqueles com fins lucrativos (incluindo pessoa física).

- Houve redução na proporção de estabelecimentos com vínculos de complementaridade com o SUS (venda de serviços) em todos os segmentos, especialmente os privados com fins lucrativos e privados mistos.

- A grande maioria dos leitos hospitalares da esfera pública (estatal e não estatal) e dos estabelecimentos privados sem fins lucrativos está disponível para o SUS, mas com redução entre os estabelecimentos dos outros órgãos da administração direta, do segmento de associações civis sem fins lucrativos e do privado filantrópico. Por outro lado, os estabelecimentos privados lucrativos reduziram bastante a proporção de leitos disponíveis para o SUS no período (de $56 \%$ para $36 \%$ ).

- Houve aumento da proporção de estabelecimentos que mantêm vínculos com o SUS sob gestão municipal em todos os segmentos, com exceção dos estabelecimentos da esfera pública não estatal, que inclui as organizações sociais de saúde. Nesse último caso, o que ocorreu foi o aumento dos estabelecimentos sob gestão estadual.

- Serviços de atenção básica estão mais presentes no segmento público estatal, embora seja interessante notar que houve aumento na proporção desse tipo de serviço entre os estabelecimentos privados mistos e redução proporcional na esfera pública.

- Serviços de média complexidade são predominantes em todos os segmentos institucionais, com destaque para os estabelecimentos privados com fins lucrativos e privados mistos; pouco mais de 70\% dos seus estabelecimentos estão concentrados nesse nível de complexidade assistencial. Além disso, o segmento de associações civis sem fins lucrativos apresentou grande variação positiva nesse tipo de serviço no período (de 36\% para 51\%).

- Serviços de alta complexidade representam uma proporção importante dos estabelecimentos da esfera privada, especialmente os filantrópicos (31\%) e lucrativos (23\%). Também são importantes nos estabelecimentos do segmento A3 - serviços do SUS pertencentes à administração indireta e que se submetem às regras do direito público (26\%) e no segmento de associações civis sem fins lucrativos $(21,2 \%)$.

- As taxas de oferta de serviços no território nacional possibilitam fazer duas constatações. A primeira é que houve aumento da oferta em todos os segmentos institucionais, com destaque 
para os seguintes segmentos: A4 - serviços do SUS pertencentes à administração indireta e que se submetem às regras do direito privado (de 5,5 para 21,1 por 10.000 habitantes); associações civis sem fins lucrativos (de 5,5 para 10,2); e privado lucrativo (de 3,4 para 9,1). O segundo aspecto é que existe uma oferta maior de serviços públicos estatais em estados das regiões Norte e Nordeste, ao passo que a oferta de serviços privados está mais concentrada nos estados das regiões Sul, Sudeste e Centro-Oeste. Já os serviços públicos não estatais apresentam taxas mais elevadas em estados de todas as regiões do país - MS, MG, SC, MT, BA e RR.

Os vínculos empregatícios dos profissionais que atuam nos diferentes segmentos institucionais tendem a ser mais fortes e estáveis nos estabelecimentos da esfera pública estatal, com predomínio de vínculos estatuários (administração direta) e contratos CLT (administração indireta, direito privado), e mais frágeis nos demais estabelecimentos. Embora na esfera privada o percentual de profissionais com contrato CLT seja importante, variando de $22 \%$ a $42 \%$, a prestação de serviços (terceirização) é o vínculo predominante nos estabelecimentos privados lucrativos (49\%) e privados mistos (36\%). Os vínculos são ainda mais frágeis nos estabelecimentos da esfera pública não estatal, nos quais os contratos temporários representam 50\% e os profissionais autônomos 30\%.

Considerados os estabelecimentos em seu conjunto, observa-se que houve um incremento de 120,5\% dos estabelecimentos de saúde cadastrados no país entre 2005 e 2013 (Figura 2). Tal aumento foi mais proeminente no setor privado $(179,4 \%)$ que no setor público $(42,3 \%)$, o que, em parte, pode ser explicado por um maior número de cadastramentos de estabelecimentos privados de pessoas físicas (com fins lucrativos). Em termos proporcionais, aproximadamente $72 \%$ dos estabelecimentos cadastrados no CNES em 2013 eram do setor privado.

No setor público há realce no incremento de cadastros de estabelecimentos nos segmentos "A4estatal de administração indireta sob a égide de direito privado" (301,2\%) e "B- associações civis sem fins lucrativos sob a égide de direito privado" (240,2\%). Tal incremento é significativamente maior do que os ocorridos nos demais segmentos do setor público (média de 42\%). Embora a proporção de estabelecimentos cadastrados nesses dois segmentos ainda seja pequena em relação ao total, respectivamente $0,16 \%$ (A4) e 0,09\% (B), observa-se uma maior inflexão tendencial de incremento no período considerado.

Do ponto de vista da divisão dos estabelecimentos nos dois ramos do direito, observa-se que o incremento de cadastramentos para estabelecimentos sob a égide do direito público foi de 40,6\% no período, ao passo que dentre aqueles cadastrados sob a égide do direito privado o crescimento foi de $180 \%$. 
Figura 2 - Incremento proporcional do número de estabelecimentos de saúde cadastrados, de acordo com os setores e segmentos institucionais. Brasil -2005-2013

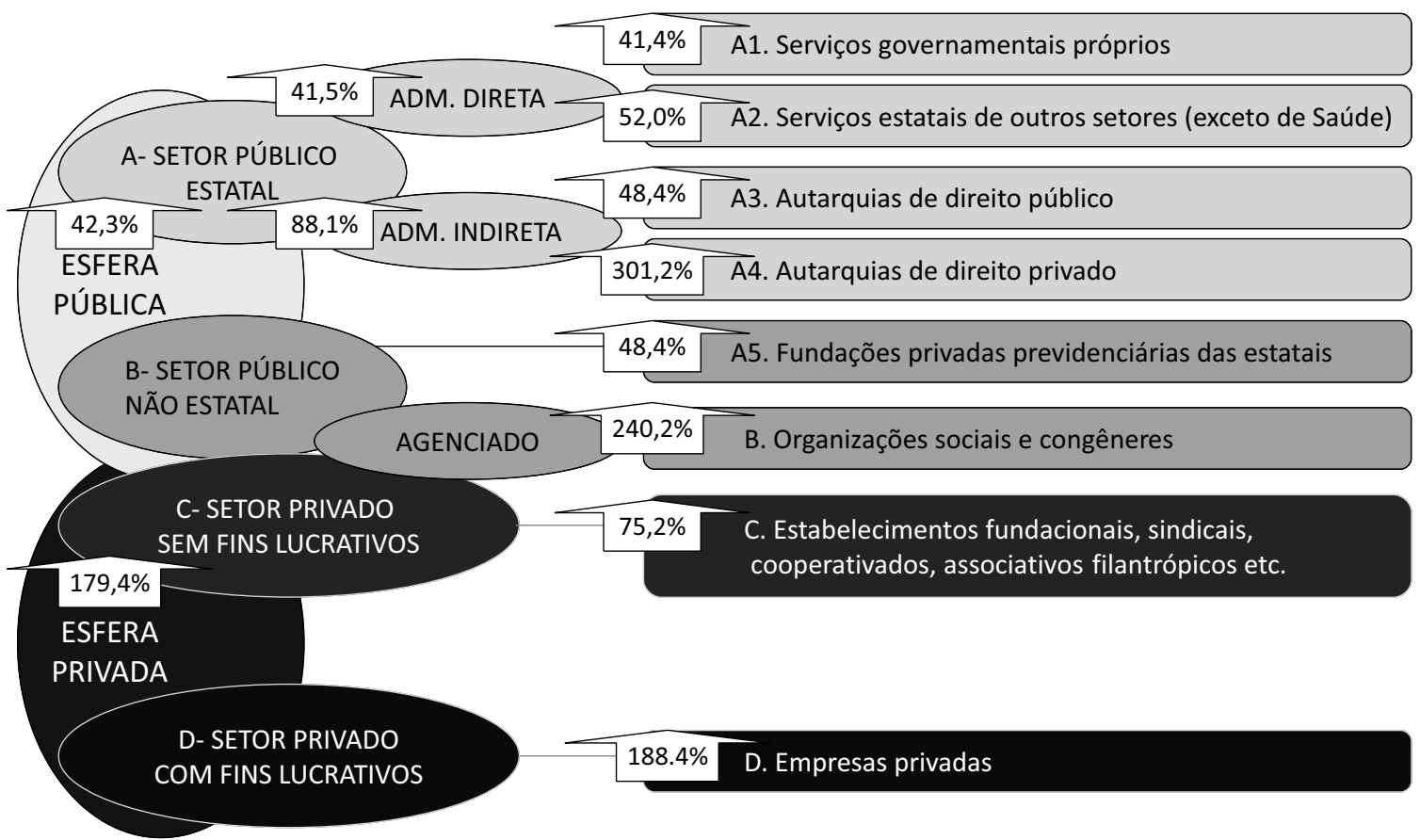

Fonte: Elaboração própria, com base em dados do DataSUS e CNES, 2013.

Com base nas variações observadas, é possível calcular a taxa média de crescimento anual para cada segmento institucional. Essas taxas podem ser visualizadas no Gráfico 1, de acordo com o qual a taxa de crescimento para o conjunto dos estabelecimentos de saúde no período foi de $10,6 \%$. A taxa também é positiva para cada um dos segmentos separadamente, embora o incremento não tenha sido o mesmo para todos os tipos de estabelecimentos. Quatro segmentos apresentaram taxas médias de incremento anual superior à média total: A4 (19\%,1); B (17,2\%); A3 (16,6\%); e D (14,9\%). Por outro lado, apresentaram crescimento abaixo da média os segmentos A1 (4,5\%), A2 (5,4\%) e C (7,4\%). 
Gráfico 1 - Taxas médias de incremento anual de estabelecimentos de saúde cadastrados (CNES), de acordo com segmentos institucionais. Brasil - 2005-2013

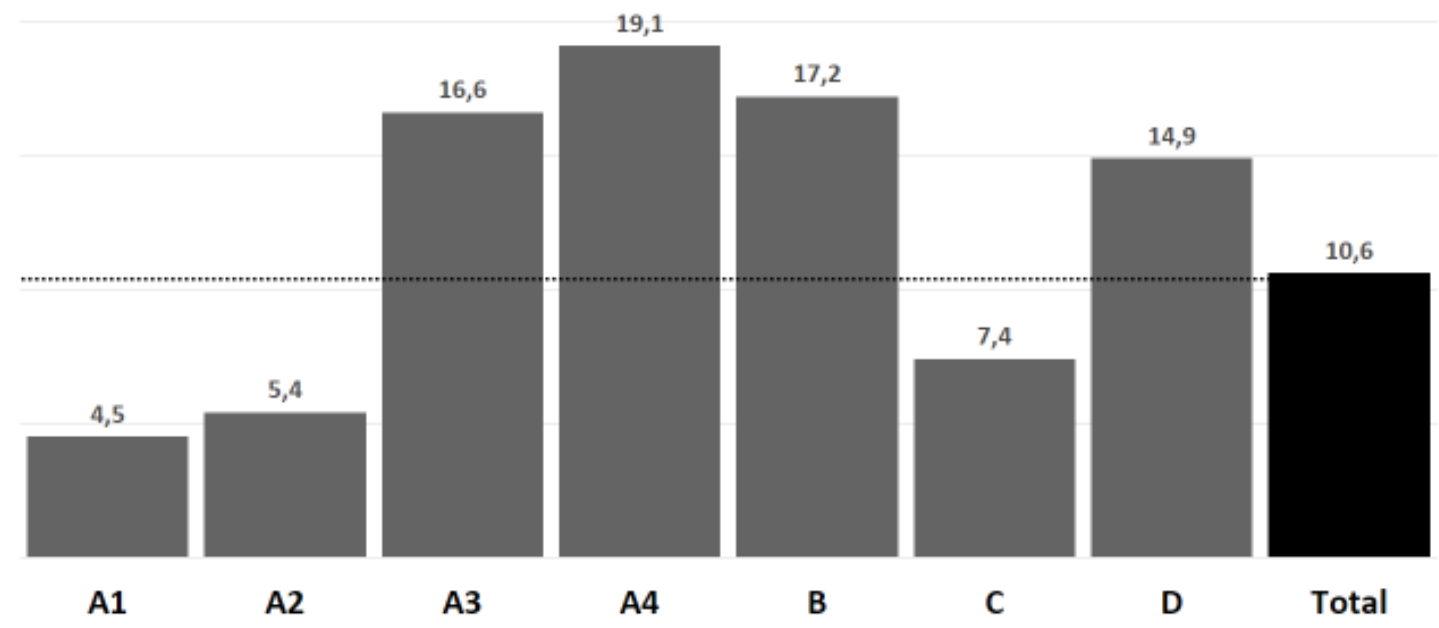

Fonte: Elaboração própria, com base em dados do DataSUS e CNES, 2013.

Considerando os aspectos tendenciais descritos retrospectivamente, denota-se, de modo mais enfático, a diminuição do peso proporcional de segmentos institucionais de gestão em saúde sob a égide administrativa do direito público, com a contrapartida de crescimento daqueles sob a égide do direito privado que já eram predominantes no conjunto. Tal tendência também se expressa para tais setores e segmentos sob a égide do direito público ou privado quando considerados especificamente os estabelecimentos com vínculo de complementaridade com o SUS.

No setor estatal, evidencia-se particularmente a tendência para o incremento de estabelecimentos sob a égide do direito privado (como empresas públicas e fundações estatais), o que, hipoteticamente, pode ser associado a alguns fatores que têm produzido constrangimentos para a expansão de serviços estatais de saúde sob a égide do direito público, tais como: subfinanciamento do setor estatal da administração direta; preponderância de transferências de recursos financeiros federais vinculados a determinadas estratégias programáticas; e limite proporcional de gastos com pessoal estabelecido pela Lei de Responsabilidade Fiscal.

Conforma-se gradualmente uma instância híbrida, a partir de segmentos públicos sob a égide do direito privado, pela confluência de serviços estatais da administração indireta (principalmente empresas públicas, fundações estatais) e serviços públicos não estatais (organizações sociais, Oscips etc.), fenômeno já identificado internacionalmente, cujas instâncias congêneres são denominadas como de "quase-mercados" (Grand, 1991; Feiok, 1998). Atualmente ainda é pequena a quantidade de serviços sob gestão pública e égide do direito privado (estatais e não estatais), mas convém realçar que os segmentos com tal característica são aqueles com maiores taxas de incremento anual e tendência 
de distribuição mais abrangente nos estados brasileiros (sem associação específica com governos de determinados partidos políticos ou outras características e conotações de natureza político-partidária).

Convém também realçar a expansão de estabelecimentos privados com fins lucrativos (D), notadamente de pessoas físicas, segmento atualmente preponderante e tendendo a um aumento proporcional ainda mais significativo nos próximos anos. Como esse segmento é o de menor vinculação complementar com o SUS (em 2013, somente 6,4\% de seus estabelecimentos), o que se projeta é a expansão de serviços suplementares, especialmente aqueles vinculados às operadoras de planos de saúde.

No caso do segmento privado sem fins lucrativos (C), o tipo de estabelecimento com tendência mais proeminente para incremento são aqueles cooperativados, principalmente as cooperativas de especialidade médicas que oferecem planos de saúde, tipo de organização que mais cresceu no período.

Acerca da distribuição de estabelecimentos de saúde de acordo com os níveis de complexidade assistencial, observa-se outra forma de segmentação, com predominância de serviços de atenção básica e de alta complexidade no setor público, estando o setor privado com a predominância de serviços de média complexidade (notadamente ambulatórios de especialidades médicas e serviços de apoio diagnóstico e terapêutico). Tal característica se torna ainda mais evidente quando se trata especificamente do conjunto de estabelecimentos vinculados ao SUS. Há uma significativa concentração de serviços de média complexidade vinculados complementarmente ao SUS nas regiões Sul e Sudeste.

Uma característica proeminente na atual configuração organizacional e logística dos setores público e privado de saúde e de seus segmentos institucionais é a ausência de integralidade da atenção. Há prescrição normativa e constitucional de integração de respostas sistêmicas e reticulares, com componentes institucionais (políticas, estratégias, ações etc.) de promoção, proteção e recuperação (assistência e reabilitação) da saúde para lidar com determinantes múltiplos, imbricados e complexos; situações e condições desiguais de risco e vulnerabilidade; decorrências e eventos também complexos etc. Do modo como os setores e segmentos institucionais de saúde estão organizados existe grande ênfase no componente médico-assistencial e correspondente defasagem estrutural nos componentes de proteção e, principalmente, de promoção da saúde. No modo de organização da institucionalidade privada essa desintegração da atenção se torna ainda mais evidente.

A setorização (pública, privada, pública-privada) e a segmentação de instituições prestadoras de serviços de saúde estão previstas constitucionalmente, assim como a pluralidade de instâncias de gestão institucional. Entretanto, trata-se de condição normativamente subordinada ao controle do poder público, com base em suas prerrogativas singulares de regulamentação, fiscalização e controle (artigo 197 da Constituição Federal - Brasil, 1988). Desse modo, a perspectiva constitucional versa sobre um pluralismo integrado sob a égide do poder público, o que põe em evidência a capacidade instituinte e regulatória do Estado brasileiro na ordenação, integração e coordenação dos diversos setores e segmentos institucionais.

Essa configuração tendencial retrospectiva acerca do tamanho e abrangência dos segmentos institucionais de gestão em saúde, quando projetada ao futuro em dinâmica inercial, ou seja, na perspectiva de que seus principais fatores determinantes e condicionantes não sejam significativamente alterados nos próximos anos, permite a projeção de um cenário mais provável em um horizonte de 
médio prazo. Se alguns dos hipotéticos fatores determinantes e condicionantes forem significativamente alterados nos próximos anos, também é possível a prospecção de configurações tendenciais distintas e cenários futuros alternativos. Algumas prospecções sumárias sobre aspectos do cenário decorrente da tendência inercial e sobre aspectos correspondentes a pelo menos dois cenários alternativos estão sumariamente descritas a seguir.

\section{Prospecção Sumária acerca de Cenários Futuros para os Segmentos Institucionais de Gestão em Saúde em Horizonte de Médio Prazo}

Em todas as tendências e cenários projetados para um horizonte de médio prazo, como até 2030, há convicção sobre a permanência de pluralismo segmentar na gestão institucional em saúde. A questão primordial que se apresenta se refere a uma caracterização sobre os prováveis tipos de pluralismo segmentar, levando-se em conta principalmente as razões, os meios e os modos implicados:

- a arquitetura segmentar, com os pesos, alcances e arranjos relativos de cada segmento institucional em função de seu provável tamanho e abrangência;

- a modelagem sistêmica e funcional de atenção à saúde, consideradas principalmente as diretrizes organizativas de hierarquização e regionalização;

- a preponderância normativa e administrativa de direito público ou privado;

- as vinculações e/ou interações com o SUS;

- o financiamento público direto e indireto;

- as vinculações empregatícias e características da força de trabalho;

- a competência e a capacidade de regulação estatal, intrínseca e extrínseca, e de controle público/social;

- os tipos preponderantes de governança sistêmica múltipla; e

- fatores diferenciais em âmbito setorial, ou seja, determinantes e condicionantes significativos intrínsecos ao setor Saúde que, uma vez mantidos ou modificados, podem consolidar ou alterar o curso de tendências e cenários futuros.

Em relação ao perfil e prioridades de problemas, necessidades e demandas de saúde para os próximos anos, optou-se por uma configuração tendencial comum para os três cenários projetados: o gradual aumento da expectativa de vida da população para outros patamares (transição demográfica) e a conjugação de eventos de causas variadas (tripla carga de doenças: agudas, crônicas e de causas externas) com proeminência de condições crônicas de evolução. Na perspectiva de tal tendência nos próximos anos os (sub)sistemas de saúde poderão estar estruturados e aptos a produzir respostas institucionais (bens, serviços etc.) compatíveis e coerentes com o perfil e as prioridades de demandas, com ênfase em reabilitação (recuperação) e medidas de apoio ao autocuidado (proteção) e de promoção da saúde, mas, também, com redes assistenciais regionalizadas. Como o referencial de tendência para demandas futuras é o mesmo para os três cenários projetados, o que se busca evidenciar são as possibilidades de reformas estruturantes para a conformação de um modelo de atenção integral compatível com a proposta do SUS. 
Além da abrangência institucional e setorial, existem múltiplos determinantes e condicionantes que podem alterar o intercurso da tendência assinalada para o perfil ou prioridades em termos de problemas, necessidades e demandas de serviços de saúde. Para o propósito específico dessa projeção de cenários, importa realçar que a tendência e cenário apontados como preponderantes para as demandas de serviços requerem inovações institucionais para aprimorar os meios, os modos e as capacidades de integração sistêmica e institucional para a produção de respostas compatíveis e impactantes que resultem na melhora das condições de saúde de indivíduos e populações. ${ }^{14}$

Um esquema sintético acerca de três prováveis cenários futuros pode ser visualizado na Figura 3: o pluralismo do empresariado sob a égide do direito privado (tendência inercial de agenciamento contratual com regulação produtiva); o pluralismo integrado sob a égide do direito público (tendência de inovação institucional focada na universalidade integral e equidade redistributiva); e o pluralismo mercantil sob a égide do direito privado (tendência de privatização subvencionada pelo poder público e regulação agenciada).

Figura 3 - Representação esquemática de três tendências e cenários possíveis para a configuração de institucionalidades de gestão em saúde no Brasil, horizonte de 2030

\section{EMPRESARIAMENTO MERCANTIL SUBVENCIONADO PELO ESTADO}

- Privatização com oligopólios mercantis, regulação contratual agenciada e ênfase na compra, oferta e consumo de tecnologias e serviços biomédicos assistenciais. Incremento de subvenções fiscais e em outras modalidades.

- Regulação "branda" e agenciada.

- Proeminência de capital estrangeiro. Preponderância na Atenção Especializada de serviços privados com fins lucrativos e suplementares ao SUS. Serviços públicos acessórios (transferência de custos) e complementares.

- Fragmentação com ênfase em assistência biomédica, sob governança operativa e contratuação procedimental.

\begin{tabular}{|c|c|}
\hline & $\begin{array}{c}\text { AGENCIAMENTO ESTATAL SOB A ÉGIDE } \\
\text { DO DIREITO PRIVADO }\end{array}$ \\
\hline $\begin{array}{l}\text { Tendência inercial } \\
\text { e cenário provável }\end{array}$ & $\begin{array}{l}\text { - Incremento de serviços qualificados como } \\
\text { públicos sob a égide do direito privado por meio }\end{array}$ \\
\hline $\begin{array}{l}\text { SUS COM “UNIVERSALISMO BÁSICO” E } \\
\text { "COMPLEMENTAR" AO SETOR PRIVADO }\end{array}$ & $\begin{array}{l}\text { interesse social e em parcerias público- } \\
\text { privadas. }\end{array}$ \\
\hline $\begin{array}{l}\text { - Provimento estatal para grupos de procedimentos de baixo } \\
\text { custo orçamentário e alta densidade populacional. Definição de } \\
\text { "pacotes básicos" de acesso universal e de "padrões de } \\
\text { integralidade" assistencial. Com a consolidação de "duplas filas" } \\
\text { e "duplas portas" de acessibilidade, constituem-se também vias }\end{array}$ & $\begin{array}{l}\text { - Oferta de "universalidade básica" e "padrões } \\
\text { de integralidade" em redes assistenciais } \\
\text { temáticas, segmentação com ênfase em } \\
\text { assistência biomédica, sob contratuação } \\
\text { procedimental e governança operativa. }\end{array}$ \\
\hline de transferências de custos do setor privado para o SUS. & - Provimento estatal com agenciamento de \\
\hline $\begin{array}{l}\text { - Subordinação aos modos de governança sistêmica e } \\
\text { procedimental, regulada pela política de diminuição de } \\
\text { "déficit primário". }\end{array}$ & $\begin{array}{l}\text { prerrogativas de gestão e autoridade sanitária, } \\
\text { regulação contratual com ênfase procedimental } \\
\text { na oferta e consumo de tecnologias e serviços } \\
\text { biomédicos assistenciais. }\end{array}$ \\
\hline
\end{tabular}

\footnotetext{
${ }^{14}$ Convém realçar que uma projeção de cenários com abrangência nacional configura contextualizações genéricas, pois pode haver concomitância ou confluência de mais de um cenário em distintas regiões e locais do país.
} 
O pluralismo do empresariado, de institucionalidade híbrida, sob a égide do direito privado (cenário I) está relacionado com uma dinâmica inercial de manutenção de vetores determinantes e condicionantes da institucionalidade da gestão em saúde. Essa tendência deve projetar um cenário futuro de consolidação da predominância quantitativa do segmento institucional privado com fins lucrativos, suplementar ao SUS e sob regulação estatal agenciada (ANS). Os tipos de estabelecimentos que mais devem crescer, em termos proporcionais e de abrangência de cobertura territorial e populacional, são: empresas públicas, fundações estatais e congêneres (segmento público estatal de administração indireta, sob a égide do direito privado) e organizações sociais, Oscips e congêneres (segmento de associações civis sem fins lucrativos). Para fins de prestação de serviços públicos, tais segmentos poderão conformar uma instância de quase-mercado regulada por relações contratuais (contratos de gestão, termos de parceria etc.) focadas na produção de procedimentos assistenciais. Denominamos esse tipo de vinculação contratual como "empresariamento" público, pois privilegia a gestão empresarial agenciada contratualmente e regulada em foco procedimental e produtivo.

O pluralismo integrado, de institucionalidade estatal, sob a égide do direito público (cenário II) depende da alteração substancial de fatores diferenciais em âmbito setorial, mas, sobremaneira, de fatores mais abrangentes, como reformas institucionais do Estado brasileiro (tributária, política etc.). Em âmbito setorial, requer inovações e reformas incrementais do setor público estatal, com ênfase e prioridade na institucionalidade sob a égide do direito público. Requer, ainda, maior provimento e melhor aporte de recursos financeiros, além de reforço na capacidade regulatória estatal e controle público/social. A arquitetura plural e segmentar estaria focada não somente em integração sistêmica como também social. Ocorreria substituição da hierarquização em níveis de complexidade assistencial por arranjos de poliarquia reticular de atenção integral, com ênfase redistributiva, visando produzir maior equidade. Universalidade integral com redes regionais de serviços, sob governança constitutiva e direcional, coordenação federativa, regulação forte e maior controle público/social. Em tal perspectiva, a capacidade regulatória estatal não estaria pautada somente em normatividade prescritiva e contratual (regulação agenciada e contratualizada), mas se daria principalmente pelo controle direto da maior parte dos serviços de saúde e da produção de insumos. Não se trataria de um processo de estatização, propriamente dito, mas de inovação na institucionalidade estatal, com maior provimento e melhor aporte de recursos financeiros para esse setor, além de reordenamento de processos de trabalho e maior integração de cargos e carreiras profissionais do SUS.

O pluralismo mercantil, de institucionalidade privada lucrativa (cenário III) apresenta como tendência projetada a privatização preponderante para o conjunto do sistema de saúde, com subvenções estatais para oligopólios mercantis de operadoras de planos de saúde, com regulação agenciada. O setor privado, filantrópico e lucrativo, além de manter a maior quantidade de estabelecimentos e serviços de saúde, obteria maior incremento proporcional, notadamente nas regiões metropolitanas do país. A característica mais significativa nesse cenário seria a inversão do sentido de complementaridade do setor privado ao setor público, ou seja, em tal perspectiva os segmentos institucionais públicos serviriam de suporte e complemento aos privados. A focalização dos serviços públicos em estratos populacionais de maiores riscos e vulnerabilidades seria outra característica marcante desse cenário. O Quadro 6 a seguir caracteriza os cenários segundo os itens considerados para sua projeção. 
Quadro 6 - Caracterização dos cenários para a configuração de institucionalidades de gestão em saúde no Brasil, horizonte de 2030

\begin{tabular}{|c|c|c|c|}
\hline Item & $\begin{array}{c}\text { Cenário I - Pluralismo do } \\
\text { empresariado, institucionalidade } \\
\text { híbrida e direito privado }\end{array}$ & $\begin{array}{c}\text { Cenário II - Pluralismo integrado, } \\
\text { institucionalidade estatal e direito } \\
\text { público }\end{array}$ & $\begin{array}{l}\text { Cenário III - Pluralismo mercantil, } \\
\text { institucionalidade e direito privados }\end{array}$ \\
\hline Arquitetura segmentar & $\begin{array}{l}\text { - Predominância do segmento institu- } \\
\text { cional privado com fins lucrativos. } \\
\text { - Incremento e consolidação de um } \\
\text { setor híbrido de quase mercado (por } \\
\text { meio da conjugação do segmento } \\
\text { estatal de administração indireta sob } \\
\text { égide do direito privado + segmento } \\
\text { de associações civis sem fins lucrati- } \\
\text { vos). } \\
\text { - Redução do segmento estatal de } \\
\text { administração direta (A1) em termos } \\
\text { proporcionais e de abrangência. }\end{array}$ & $\begin{array}{l}\text { - Ampliação proporcional dos segmentos } \\
\text { estatais da administração direta e nota- } \\
\text { damente da administração indireta sob } \\
\text { a égide de direito público (A4). } \\
\text { - Consolidação de nichos do setor priva- } \\
\text { do (filantrópico e lucrativo) com ênfase } \\
\text { em sua vinculação complementar ao } \\
\text { SUS. } \\
\text { - Maior ampliação do segmento estatal } \\
\text { de administração indireta sob a égide } \\
\text { do direito privado (A4) e segmento de } \\
\text { associações civis sem fins lucrativos na } \\
\text { produção de insumos. }\end{array}$ & $\begin{array}{l}\text { - Consolidação da predominância do } \\
\text { segmento institucional privado com } \\
\text { fins lucrativos. } \\
\text { - Incremento e consolidação de um } \\
\text { setor híbrido de quase mercado (por } \\
\text { meio da conjugação do segmento } \\
\text { estatal de administração indireta sob } \\
\text { égide do direito privado + segmento } \\
\text { de associações civis sem fins lucrati- } \\
\text { vos). Redução do segmento estatal de } \\
\text { administração direta (A1) em termos } \\
\text { proporcionais e de abrangência. } \\
\text { - Ampliação do segmento misto (E), } \\
\text { com ênfase no tipo específico de } \\
\text { parcerias público-privadas para inves- } \\
\text { timentos em serviços hospitalares e } \\
\text { ambulatoriais especializados. }\end{array}$ \\
\hline $\begin{array}{l}\text { Modelo de atenção à } \\
\text { saúde }\end{array}$ & $\begin{array}{l}\text { - Segmentação dos níveis de complexi- } \\
\text { dade assistencial, com padronização } \\
\text { da oferta de serviços e procedimentos } \\
\text { de acessibilidade universal, de acordo } \\
\text { com a disponibilidade de recursos } \\
\text { públicos e critérios de eficiência } \\
\text { (universalismo básico). } .^{15} \\
\text { - Integralidade em xeque em virtude } \\
\text { das diversas formas de segmentação } \\
\text { sistêmica e da fragmentação das } \\
\text { instâncias de gestão (notadamente } \\
\text { aquelas sob contratos públicos). } \\
\text { - Ênfase em arranjos público-privados, } \\
\text { híbridos ou combinados. }\end{array}$ & $\begin{array}{l}\text { - Ênfase na estruturação da atenção } \\
\text { básica como instância de coordenação } \\
\text { de redes de atenção integral à saúde. } \\
\text { - Inovações e criação de políticas, estraté- } \\
\text { gias, serviços e ações intersetoriais para } \\
\text { a promoção e proteção da saúde, para } \\
\text { além dos serviços de vigilância. } \\
\text { - Serviços de assistências organizados em } \\
\text { redes integradas, a partir de itinerários } \\
\text { de cuidado considerados prioritários em } \\
\text { distintas e diversas regiões. } \\
\text { - Universalidade no acesso aos serviços } \\
\text { de atenção integral à saúde em âmbito } \\
\text { regional, com ênfase em equidade } \\
\text { redistributiva. }\end{array}$ & $\begin{array}{l}\text { - Segmentação dos níveis de complexi- } \\
\text { dade assistencial. } \\
\text { - Acessibilidade universal contemplando } \\
\text { procedimentos de menor lucratividade } \\
\text { para o mercado, além de algumas } \\
\text { estratégias e ações programáticas de } \\
\text { baixo custo orçamentário estatal. } \\
\text { - Planos de saúde subvencionados pelo } \\
\text { Estado e focados em procedimentos } \\
\text { ambulatoriais médicos especializados, } \\
\text { mas com baixa densidade tecnológica. } \\
\text { - Regionalização focada em serviços de } \\
\text { média complexidade, dependentes de } \\
\text { mercado e quase mercado. }\end{array}$ \\
\hline
\end{tabular}

${ }^{15}$ Filgueira e colaboradores (2006). 


\begin{tabular}{|c|c|c|c|}
\hline Item & $\begin{array}{l}\text { Cenário I - Pluralismo do } \\
\text { empresariado, institucionalidade } \\
\text { híbrida e direito privado }\end{array}$ & $\begin{array}{c}\text { Cenário II - Pluralismo integrado, } \\
\text { institucionalidade estatal e direito } \\
\text { público }\end{array}$ & $\begin{array}{l}\text { Cenário III - Pluralismo mercantil, } \\
\text { institucionalidade e direito privados }\end{array}$ \\
\hline $\begin{array}{l}\text { Preponderância } \\
\text { administrativa e jurídica }\end{array}$ & $\begin{array}{l}\text { Predomínio dos serviços gerenciados } \\
\text { sob a égide do direito privado, com } \\
\text { ênfase na garantia de oferta, acessibi- } \\
\text { lidade e consumo de procedimentos } \\
\text { assistenciais padronizados. }\end{array}$ & $\begin{array}{l}\text { - Predomínio de serviços sob a égide do } \\
\text { direito público, tanto da administração } \\
\text { direta (nos municípios) como indireta } \\
\text { (nas regiões de saúde). } \\
\text { - Estabelecimentos privados filantrópicos } \\
\text { e lucrativos permanecem sob a égide do } \\
\text { direito privado. }\end{array}$ & $\begin{array}{l}\text { - Preponderância de serviços sob a } \\
\text { égide do direito privado e dinâmicas } \\
\text { de mercado. }\end{array}$ \\
\hline Relação com o SUS & $\begin{array}{l}\text { Preponderância de serviços suple- } \\
\text { mentares ao SUS, porém de menor } \\
\text { abrangência territorial e com foco em } \\
\text { assistência ambulatorial especializada } \\
\text { e serviços de apoio diagnóstico e } \\
\text { terapêutico. } \\
\text { - Os serviços próprios do SUS poderão } \\
\text { ser complementares ao setor privado, } \\
\text { ao invés do que está estabelecido } \\
\text { constitucionalmente. }\end{array}$ & $\begin{array}{l}\text { - Preponderância quantitativa de serviços } \\
\text { próprios do SUS, com distribuição } \\
\text { abrangente. } \\
\text { - Os serviços privados do segmento de } \\
\text { associaçes civis sem fins lucrativos } \\
\text { com vínculo complementar ao SUS } \\
\text { estariam focados em procedimentos } \\
\text { de média complexidade hospitalar e } \\
\text { ambulatorial. }\end{array}$ & $\begin{array}{l}\text { - Preponderância de serviços suple- } \\
\text { mentares ao SUS, porém de menor } \\
\text { abrangência territorial e com foco em } \\
\text { assistência ambulatorial especializada } \\
\text { e serviços de apoio diagnóstico e } \\
\text { terapêutico. } \\
\text { - Os serviços próprios do SUS poderão } \\
\text { estar disponibilizados para atender } \\
\text { procedimentos básicos ou com } \\
\text { enfoque específico (determinadas } \\
\text { condições de risco e vulnerabilidade). }\end{array}$ \\
\hline Financiamento público & $\begin{array}{l}\text { - Financiamento público direto insufi- } \\
\text { ciente para as demandas de investi- } \\
\text { mentos necessários para a ampliação } \\
\text { de serviços e focado no custeio de } \\
\text { ofertas padronizadas. } \\
\text { - Manutenção de subvenções e } \\
\text { subsídios indiretos estatais para } \\
\text { os serviços suplementares ao SUS, } \\
\text { principalmente por meio de renúncias } \\
\text { fiscais e isenções para pessoas físicas } \\
\text { e jurídicas. }\end{array}$ & $\begin{array}{l}\text { - Financiamento público direto gra- } \\
\text { dualmente incrementado até atingir } \\
\text { o patamar (em relação ao PIB) do } \\
\text { gasto público em países com sistemas } \\
\text { universais de saúde de menor porte } \\
\text { populacional. } \\
\text { - Diminuição de subvenções e subsídios } \\
\text { indiretos estatais para os serviços suple- } \\
\text { mentares ao SUS (planos de saúde). }\end{array}$ & $\begin{array}{l}\text { - Financiamento público direto insufi- } \\
\text { ciente para as demandas de investi- } \\
\text { mentos necessários para a ampliação } \\
\text { de serviços e focado no custeio de } \\
\text { ofertas padronizadas. } \\
\text { - Ampliações de subvenções, subsídios } \\
\text { (diretos e indiretos) e isenções tribu- } \\
\text { tárias para o setor privado. } \\
\text { - Maior aporte de recursos estatais para } \\
\text { o segmento Associações Civis sem fins } \\
\text { lucrativos (B). }\end{array}$ \\
\hline
\end{tabular}




\begin{tabular}{|c|c|c|c|}
\hline Item & $\begin{array}{l}\text { Cenário I - Pluralismo do } \\
\text { empresariado, institucionalidade } \\
\text { híbrida e direito privado }\end{array}$ & $\begin{array}{c}\text { Cenário II - Pluralismo integrado, } \\
\text { institucionalidade estatal e direito } \\
\text { público }\end{array}$ & $\begin{array}{l}\text { Cenário III - Pluralismo mercantil, } \\
\text { institucionalidade e direito privados }\end{array}$ \\
\hline $\begin{array}{l}\text { Vínculos empregatícios } \\
\text { e características da força } \\
\text { de trabalho }\end{array}$ & $\begin{array}{l}\text { - Redução de servidores públicos sob } \\
\text { regime estatutário, incremento pro- } \\
\text { porcional de servidores públicos sob } \\
\text { regime CLT. } \\
\text { - Aumento de vínculos de trabalhado- } \\
\text { res autônomos (notadamente no setor } \\
\text { privado) e com contratos temporários } \\
\text { (setor privado e segmento de associa- } \\
\text { ções civis sem fins lucrativos). } \\
\text { - Os serviços com atividades de ensino } \\
\text { poderão estar concentrados no segmen- } \\
\text { to estatal de administração indireta sob } \\
\text { égide do direto privado (A4). }\end{array}$ & $\begin{array}{l}\text { - Prevalência de vínculos de emprego } \\
\text { público sob regime celetista, com } \\
\text { diminuição de contratos temporários e } \\
\text { informais. } \\
\text { - Os vínculos estatutários poderão dimi- } \\
\text { nuir gradualmente, mas permanecerão } \\
\text { significativos principalmente em muni- } \\
\text { cípios de pequeno porte populacional. } \\
\text { - No setor privado também prevaleceriam } \\
\text { vínculos de CLT. }\end{array}$ & $\begin{array}{l}\text { - Predominância de empregados autô- } \\
\text { nomos e terceirizados. } \\
\text { - Redução significativa de servidores } \\
\text { públicos sob regime estatutário, } \\
\text { incremento proporcional de servidores } \\
\text { públicos sob regime CLT. }\end{array}$ \\
\hline $\begin{array}{l}\text { Capacidade de regulação } \\
\text { estatal e controle } \\
\text { público/social }\end{array}$ & $\begin{array}{l}\text { - Para o setor privado e suplementar } \\
\text { ao SUS poderá persistir o modelo de } \\
\text { regulação agenciada, com ênfase na } \\
\text { garantia de consumo de procedimen- } \\
\text { tos de baixo e médio custos. } \\
\text { - Para os segmentos que compõem } \\
\text { o setor de quase-mercado poderá } \\
\text { prevalecer a regulação pautada em } \\
\text { contratos com ênfase em eficiência } \\
\text { procedimental e produtiva. } \\
\text { - Dificuldade para manter e ampliar } \\
\text { os espaços de controle público/social } \\
\text { (para além das instâncias de defesa } \\
\text { de consumidores). }\end{array}$ & $\begin{array}{l}\text { - A regulação estatal do conjunto de } \\
\text { segmentos institucionais de saúde } \\
\text { ocorreria tanto por prerrogativa e via } \\
\text { normativa, como em função de maior } \\
\text { controle estatal sobre a oferta de servi- } \\
\text { ços próprios. } \\
\text { - Os contratos organizativos entre entes } \\
\text { públicos e estatais tenderiam a regular } \\
\text { a articulação interfederativa em âmbito } \\
\text { regional, pautados em propósitos de } \\
\text { integralidade e metas de curto, médio e } \\
\text { longo prazos. } \\
\text { - A regulação dos segmentos não esta- } \\
\text { tais ocorreria por meio de contratos } \\
\text { ampliados e pautados em garantias de } \\
\text { princípios e diretrizes constitucionais, } \\
\text { com controle público/social e ênfase em } \\
\text { metas regionais. } \\
\text { - A regulação agenciada dos segmentos } \\
\text { privados seria mais restrita e específica, } \\
\text { com ênfase na garantia de atenção } \\
\text { integral à saúde dos beneficiários. }\end{array}$ & $\begin{array}{l}\text { - Ênfase em regulação agenciada com } \\
\text { foco em garantia de acessibilidade de } \\
\text { beneficiários de serviços privados a } \\
\text { procedimentos padronizados. } \\
\text { - } \text { Regulação contratual com o segmento } \\
\text { estatal da administração indireta sob } \\
\text { a égide do direito privado (A4) e com } \\
\text { o segmento associações civis sem fins } \\
\text { lucrativos (B). } \\
\text { - Ausência de controle público/social } \\
\text { dos serviços de mercado e quase } \\
\text { mercado, com restrição ao segmento } \\
\text { estatal de administração direta da } \\
\text { saúde (A1). }\end{array}$ \\
\hline
\end{tabular}




\begin{tabular}{|c|c|c|c|}
\hline Item & $\begin{array}{l}\text { Cenário I - Pluralismo do } \\
\text { empresariado, institucionalidade } \\
\text { híbrida e direito privado }\end{array}$ & $\begin{array}{c}\text { Cenário II - Pluralismo integrado, } \\
\text { institucionalidade estatal e direito } \\
\text { público }\end{array}$ & $\begin{array}{l}\text { Cenário III - Pluralismo mercantil, } \\
\text { institucionalidade e direito privados }\end{array}$ \\
\hline $\begin{array}{l}\text { Tipos preponderantes de } \\
\text { governança sistêmica }\end{array}$ & $\begin{array}{l}\text { - Predomínio de modos de governança } \\
\text { mais operativa e procedimental. } \\
\text { - Em termos organizacionais, modos de } \\
\text { governança mais administrativa; em } \\
\text { termos individuais, modos de gover- } \\
\text { nança de contatos administrativos. } \\
\text { - Os modos de governança constitutiva } \\
\text { e diretiva poderão ser fracos e insu- } \\
\text { ficientes para alterar o intercurso de } \\
\text { tendência inercial. }\end{array}$ & $\begin{array}{l}\text { - Ocorrência simultânea de modos de } \\
\text { governança constitutiva, diretiva e } \\
\text { operativa para o setor público, estatal e } \\
\text { não estatal. } \\
\text { - Comissões intergestoras do SUS como } \\
\text { instâncias proeminentes de processos } \\
\text { decisórios federativos para os modos } \\
\text { de governança diretiva, em articulação } \\
\text { com instâncias de controle público/ } \\
\text { social. } \\
\text { - Em termos organizacionais, coexistên- } \\
\text { cia de modos de governança de relações } \\
\text { contextuais, de suporte e relações } \\
\text { administrativas. Em termos individuais, } \\
\text { modos de governança de normas profis- } \\
\text { sionais, fronteiras individuais e contatos } \\
\text { administrativos. }\end{array}$ & $\begin{array}{l}\text { Predomínio de modos de governança } \\
\text { mais operativa e procedimental, } \\
\text { com foco em mediações de caráter } \\
\text { mercantil (acomodação de interesses } \\
\text { corporativos e de oligopólios). } \\
\text { - Em termos organizacionais, um modo } \\
\text { de governança mais administrativa de } \\
\text { mercado; em termos individuais, um } \\
\text { modo de governaça mais focada em } \\
\text { contratos administrativos. }\end{array}$ \\
\hline
\end{tabular}




\section{Referências}

ABRUCIO, F. L. Trajetória recente da gestão pública brasileira: um balanço crítico e a renovação da agenda de reformas. Revista de Administração Pública, 41(número especial): 67-86, 2007. Disponível em: <http://dx.doi. org/10.1590/S0034-76122007000700005 > . Acesso em: 10 jun. 2014.

BRASIL. Constituição da República Federativa do Brasil de 1988. Brasília, Diário Oficial da União, 1988. Disponível em: <www.planalto.gov.br/ccivil_03/constituicao/constituicao.htm>. Acesso em: 10 jun. 2014.

CASTLES, F. G. The Future of the Welfare State: Crisis Myths and Crisis Realities. Oxford: Oxford University Press, 2004.

DAIN, S. Do Direito Social à Mercadoria, 2000. Tese de Concurso para Professor Titular, Rio de Janeiro: Instituto de Medicina Social, Universidade do Estado do Rio de Janeiro.

DEPARTAMENTO DE INFORMÁTICA DO SUS (DATASUS) \& CADASTRO NACIONAL DE ESTABELECIMENTOS DE SAÚDE (CNES). CNES Estabelecimentos, 2013. Disponível em: < http://www2.datasus.gov.br/DATASUS/ index.php? area $=0204 \& i d=6906>$. Acesso em: março 2016.

DRAIBE, S. \& HENRIQUE, W. "Welfarestate", crise e gestão da crise: um balanço da literatura internacional. Revista Brasileira de Ciências Sociais, 3(6): 53-78, 1988.

FEIOCK, R. C. A Quasi-Market Theory of Local Development Competition. Florida: Florida State University, 1998. Disponível em: <http://localgov.fsu.edu/papers/archive/Feiock_001.pdf>. Acesso em: 10 jun. 2014.

FERLIE, E. et al. A Nova Administração Pública em Ação. Brasília: Editora da Universidade de Brasília, 1999.

FILGUEIRA, F. et al. Universalismo básico: Una nueva política social para América Latina. In: INTER-AMERICAN DEVELOPMENT BANK AND PLANETA, 2006, Washington. (Working paper series)

GRAND, J. L. Quasi-Markets and Social Policy. The Economic Journal, 101(408): 1.256-1.267, 1991.

HAM, C. Health Care Reform: learning from international experience. Philadelphia: Open University Press, 1997.

HUPE, P. L. \& HIIL, M. J. The three action levels of governance: reframing the policy process beyond the stages model. In: PETERS, B. G. \& PIERRE, J. Handbook of Public Policy. London: Sage, 2006.

LEVI, M. L. \& SCATENA, J. H. G. Evolução recente do financiamento do SUS e considerações sobre o processo de regionalização. In: VIANA, A. L. D. \& LIMA, L. D. (Orgs.). Regionalização e Relações Federativas na Política de Saúde do Brasil. Rio de Janeiro: Contracapa, 2011.

MAJONE, G. Do Estado Positivo ao Estado Regulador: causas e consequências de mudança no modo de governança. Revista do Serviço Público, 50(1): 5-36, 1999.

MATTOS, R. A. As agências internacionais e as políticas de saúde nos anos 90: um panorama geral da oferta de ideias. Ciência \& Saúde Coletiva, 6(2): 377-389, 2001.

MÉDICI, A. C. Aspectos teóricos e conceituais do financiamento das políticas de saúde. In: PIOLA, S. F. \& VIANNA, S. M. (Orgs.). Economia da Saúde: conceitos e contribuição para a gestão da saúde. Brasília: Ipea, 1995.

MÉRRIEN, F. X. L' État Providence. Paris: Puf, 1994. (Collection Que Sais Je?)

MILWARD, H. B. \& PROVAN, K. G. How networks are governed. In: CAROLYN, H. \& LYNN, L. E. (Eds.). Governance and Performance: new perspectives. Washington: Georgetown University Press, 2000.

NÚCLEO DE ESTUDOS DE POLÍTICAS PÚBLICAS (NEPP). Levantamentos Preliminares dos Serviços de Saúde Públicos e Privados na América Latina e Caribe. Campinas: NEPP, 2003.

OSBORNE, D. \& GAEBLER, T. Reinventando o Governo: como o espírito empreendedor está transformando o setor público. Brasília: Mh Comunicação, 1994. 
OSBORNE, S. P. The New Public Governance? Emerging perspectives on the theory and practice of public governance. New York: Routledge, 2010.

PAHIM, M. L. L. Organizações Sociais de Saúde do Estado de São Paulo: inserção privada no SUS e gestão financeira do modelo pela Secretaria de Estado da Saúde, 2009. Tese de Doutorado, São Paulo: Faculdade de Medicina, Universidade de São Paulo. Disponível em: <www.teses.usp.br/teses/disponiveis/5/5137/tde-08122009185716/pt-br.php>. Acesso em: 12 jun. 2014.

PEREIRA, L. C. B. A Reforma do Estado dos anos 90: lógica e mecanismos de controle. Brasília: Ministério da Administração Federal e Reforma do Estado, 1997. (Cadernos Mare, 1)

PIERSON, C. Beyond the Welfare State? The new political economy of welfare. Texas: Penn State University Press, 1998.

PIERSON, P. Dismantling the Welfare State? Reagan, Thatcher and the politics of retrenchment. Cambridge: Cambridge University Press, 1994.

REZENDE, F. C. Tendências da gestão pública nos países da OCDE. In: LEVY, E. \& DRAGO, P. A. Gestão Pública no Brasil Contemporâneo. São Paulo: Fundap, 2005.

RICHARDS, D. \& SMITH, M. Governance and Public Policy in the UK. Oxford: Oxford University Press, 2002.

SILVA, P. L. B. Serviços de Saúde: o dilema do SUS na nova década. São Paulo em Perspectiva, 17(1): 69-85, 2003.

SMITH, A. Governança de múltiplos níveis: o que é e como pode ser estudada. In: PETERS, B. G. \& PIERRE, J. (Orgs.). Administração Pública: coletânea. São Paulo: Editora Unesp, 2010.

TENÓRIO, F. G. \& SARAVIA, E. J. Esforços sobre gestão pública e gestão social: as recentes reformas do Estado. In: MARTINS, P. E. M. \& PIERANTI, O. P. Estado e Gestão Pública: visões do Brasil contemporâneo. 2. ed. Rio de Janeiro: FGV, 2006.

VIANA, A. L. \& SILVA, H. P. Desenvolvimento e institucionalidade da política social no Brasil. In: MACHADO, C. V.; BAPTISTA, T. W. F. \& LIMA, L. D. (Orgs.). Políticas de Saúde no Brasil: continuidades e mudanças. Rio de Janeiro: Editora Fiocruz, 2012.

VIANA, A. L. et al. Pesquisa Política, planejamento e gestão das regiões e redes de Saúde. Cnpq/MS, Banco de Indicadores, 2013. Disponível em: <www.resbr.net.br>. Acesso em: 17 jun. 2014. 


\section{ANEXO}

Nos mapas apresentados a seguir estão georreferenciados estratos de taxas de oferta populacional para estabelecimentos de saúde nos estados brasileiros, considerados os períodos de julho de 2005 e 2013 e de acordo com as principais modalidades administrativas tratadas no capítulo. Para o cálculo de denominadores populacionais foram utilizadas diversas escalas (10.000 habitantes, 1.000.000 habitantes, 10.000.00 habitantes) em razão de distintas magnitudes de oferta e do propósito específico de realçar os estados brasileiros com maiores incrementos de taxas de oferta das distintas modalidades administrativas.

Figura 1 - Segmento de Administração Direta, égide de direito público, serviços governamentais próprios do Sistema Único de Saúde (A1)

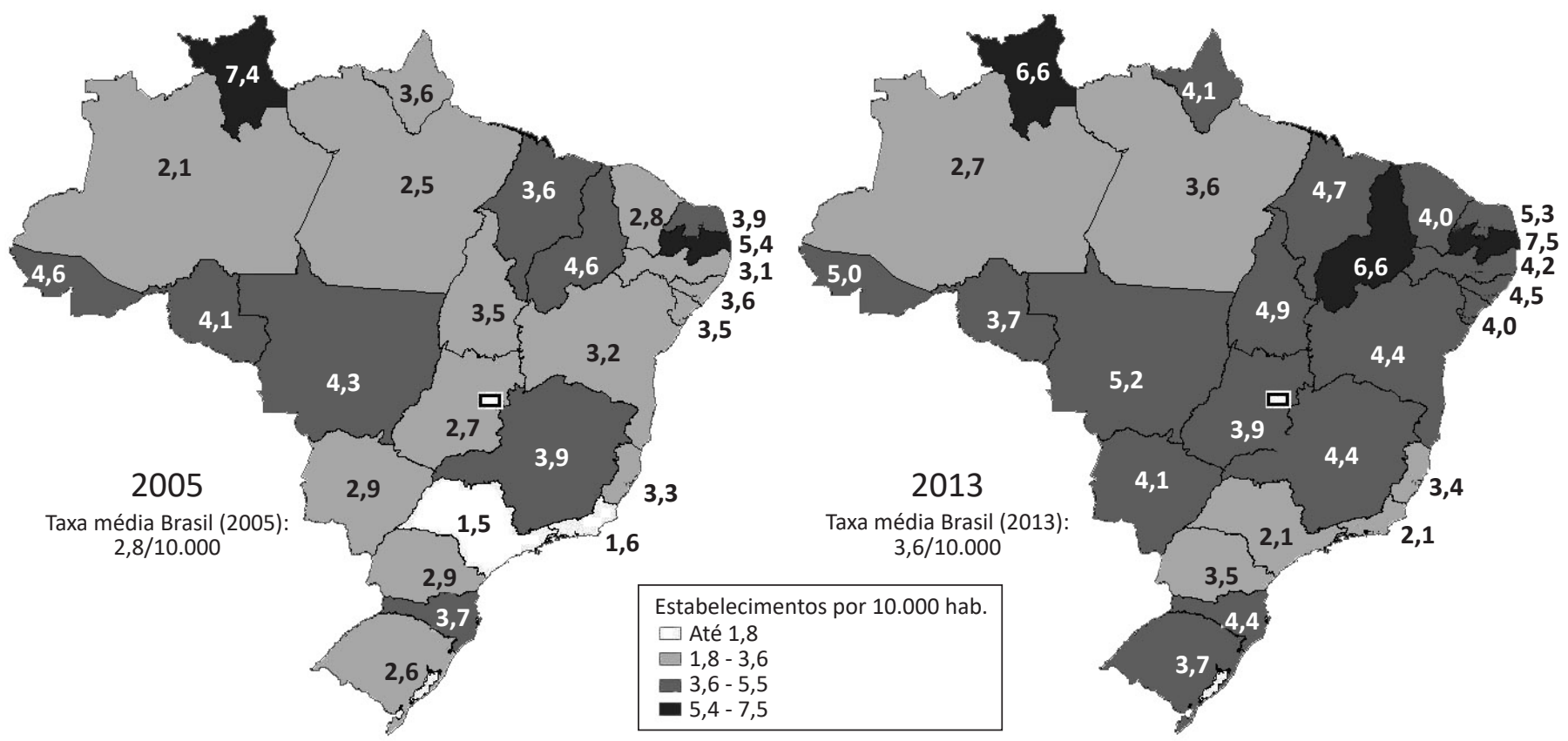

Fonte: DataSUS \& CNES, 2013. 
Figura 2 - Segmento de administração direta, outros órgãos estatais (exceto órgãos governamentais de Saúde), égide do direito público, serviços complementares ao SUS e suplementares (A2)

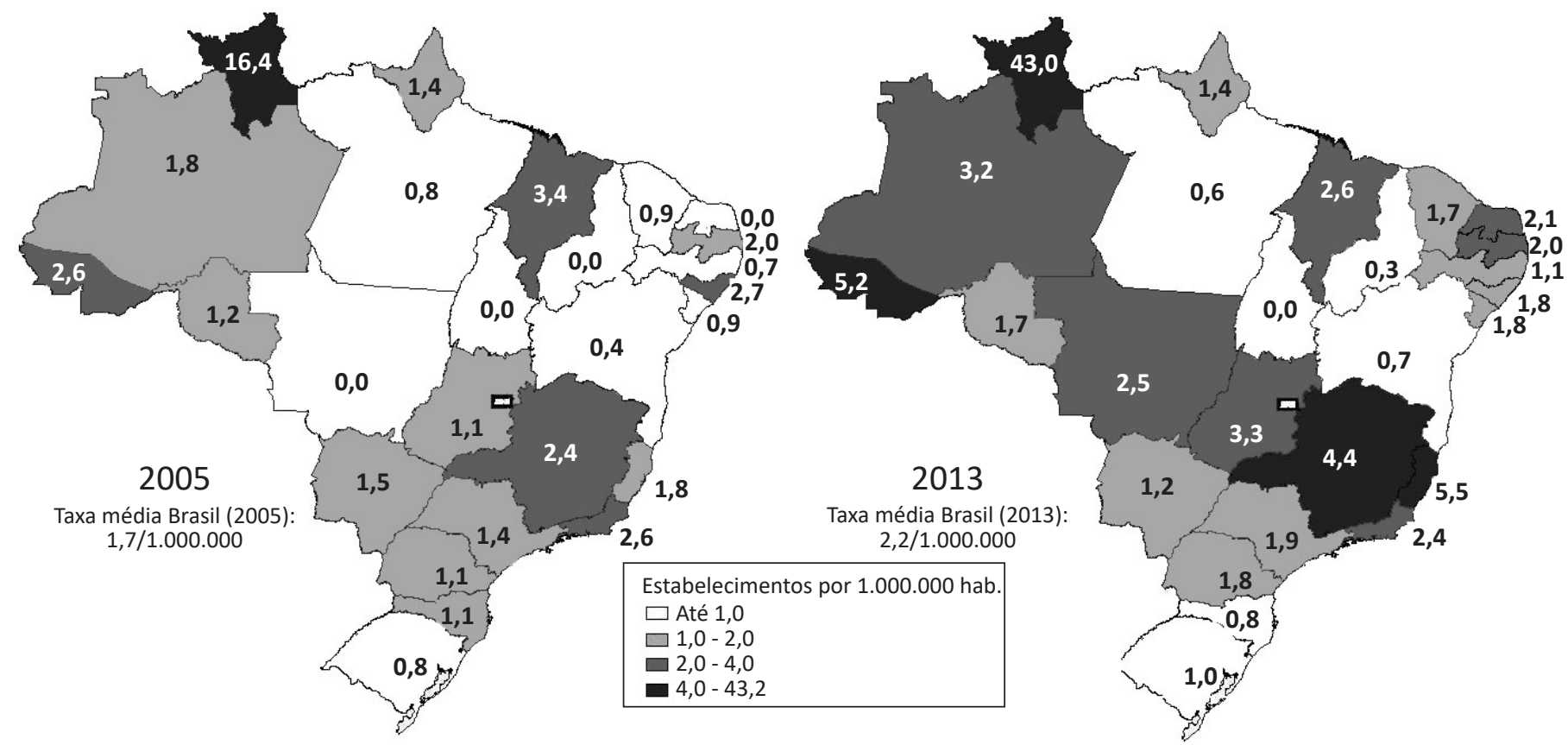

Fonte: DataSUS \& CNES, 2013.

Figura 3 - Segmento de administração indireta, égide do direito público, serviços próprios do SUS (A3)

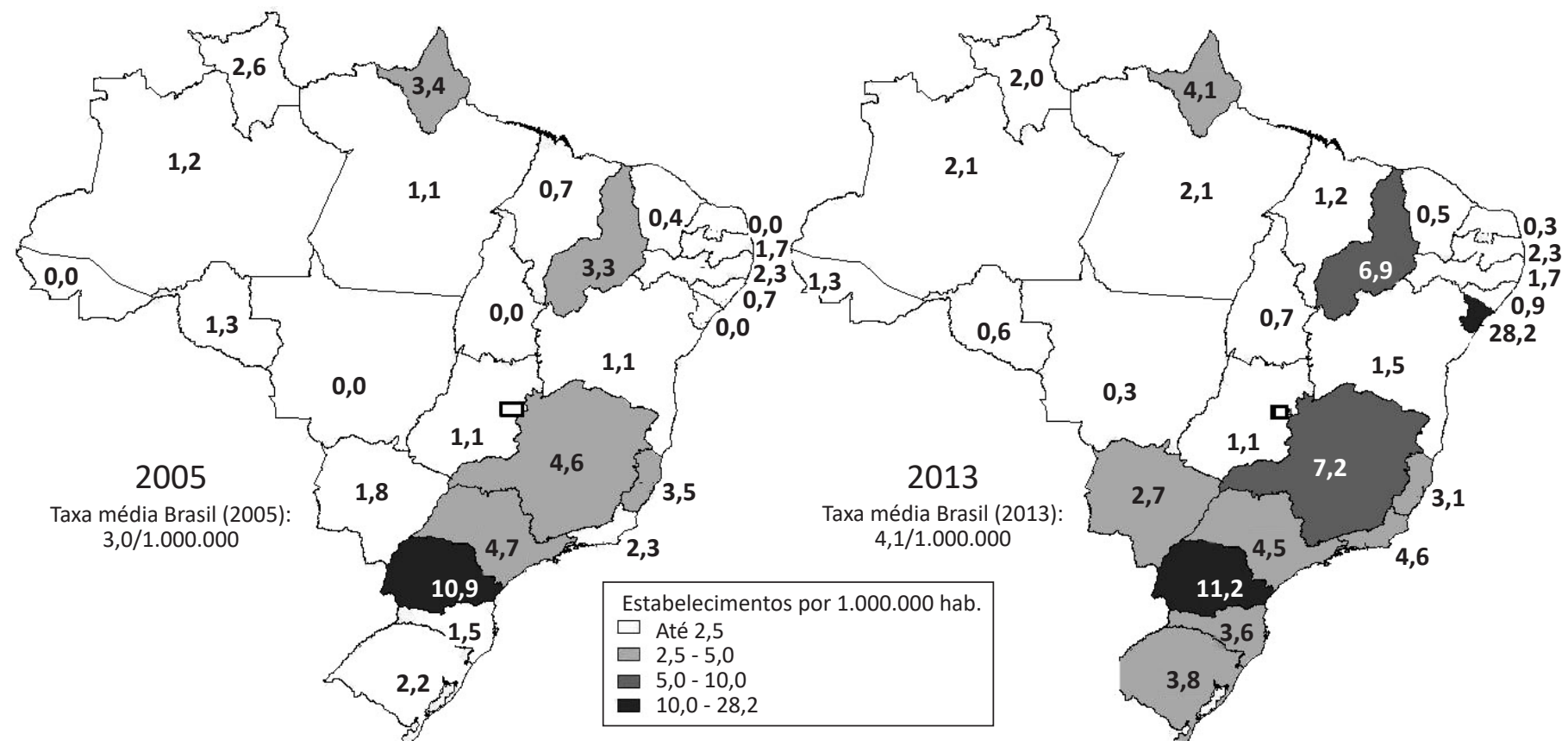

Fonte: DataSUS \& CNES, 2013. 
Figura 4 - Segmento de administração indireta, égide do direito privado, serviços próprios do SUS (A4)

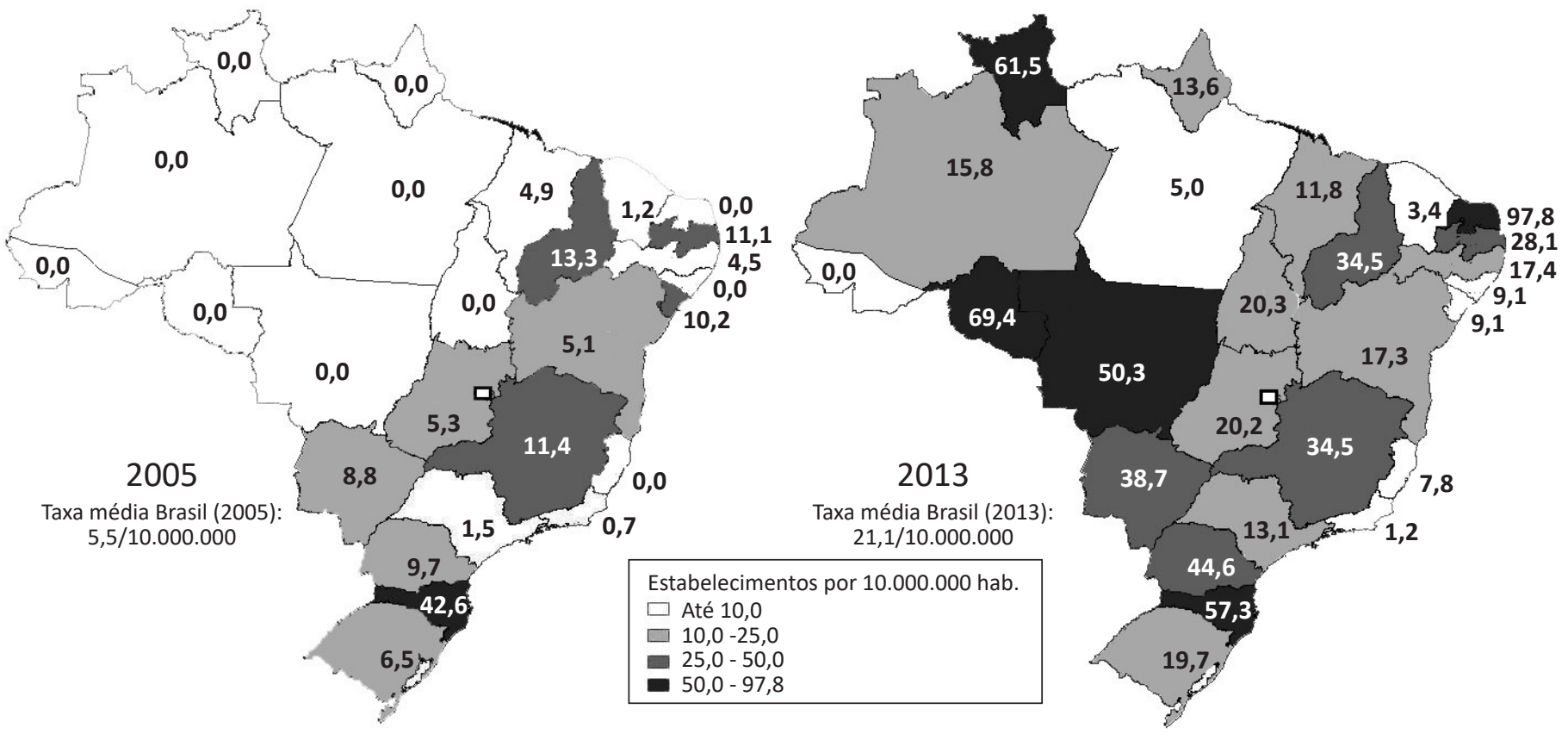

Fonte: DataSUS \& CNES, 2013.

Figura 5 - Segmento de serviços públicos não estatais, égide do direito privado, com serviços complementares contratados pelo SUS e serviços suplementares (B)

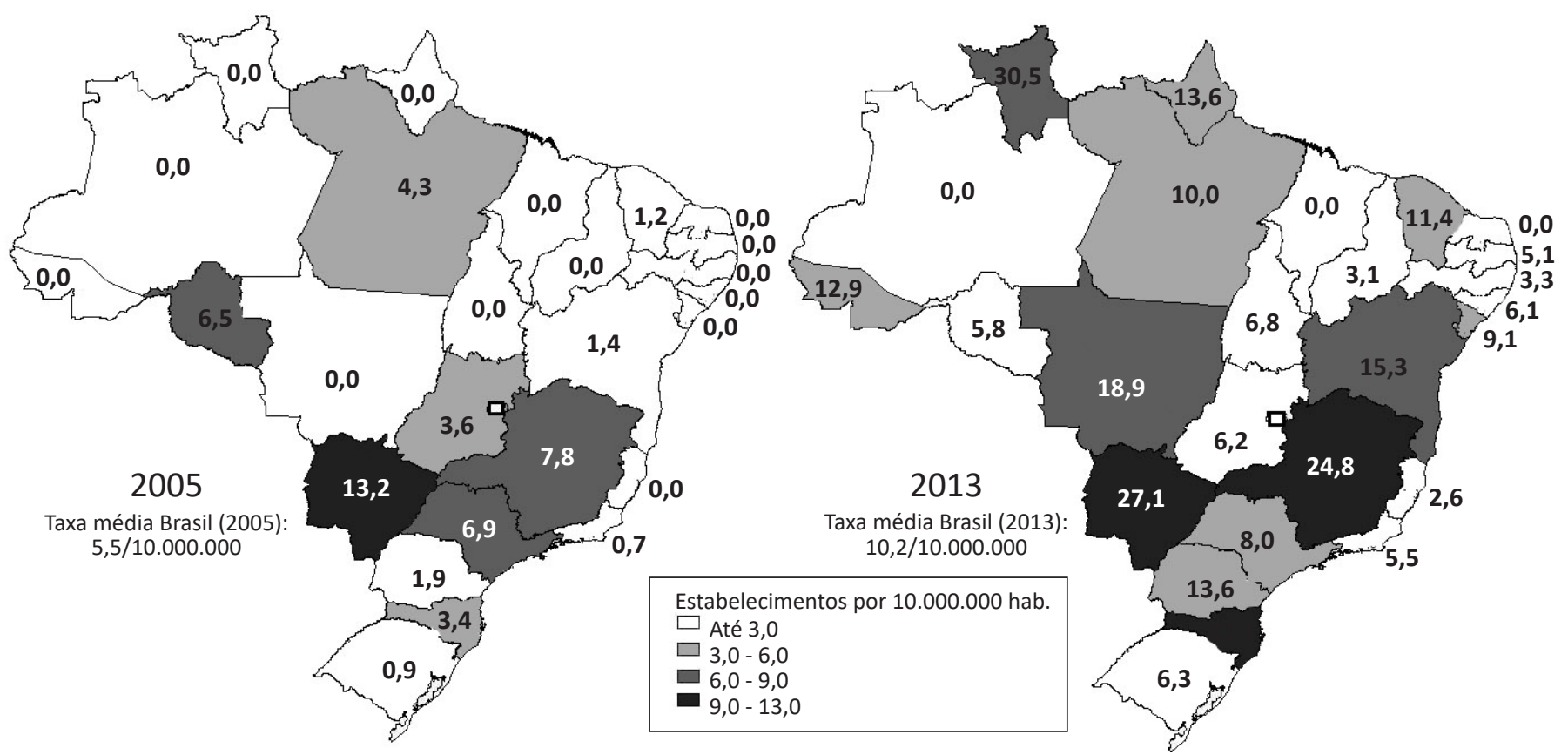

Fonte: DataSUS \& CNES, 2013. 
Figura 6 - Segmento privado sem fins lucrativos, com serviços complementares conveniados ao SUS e serviços suplementares (C)

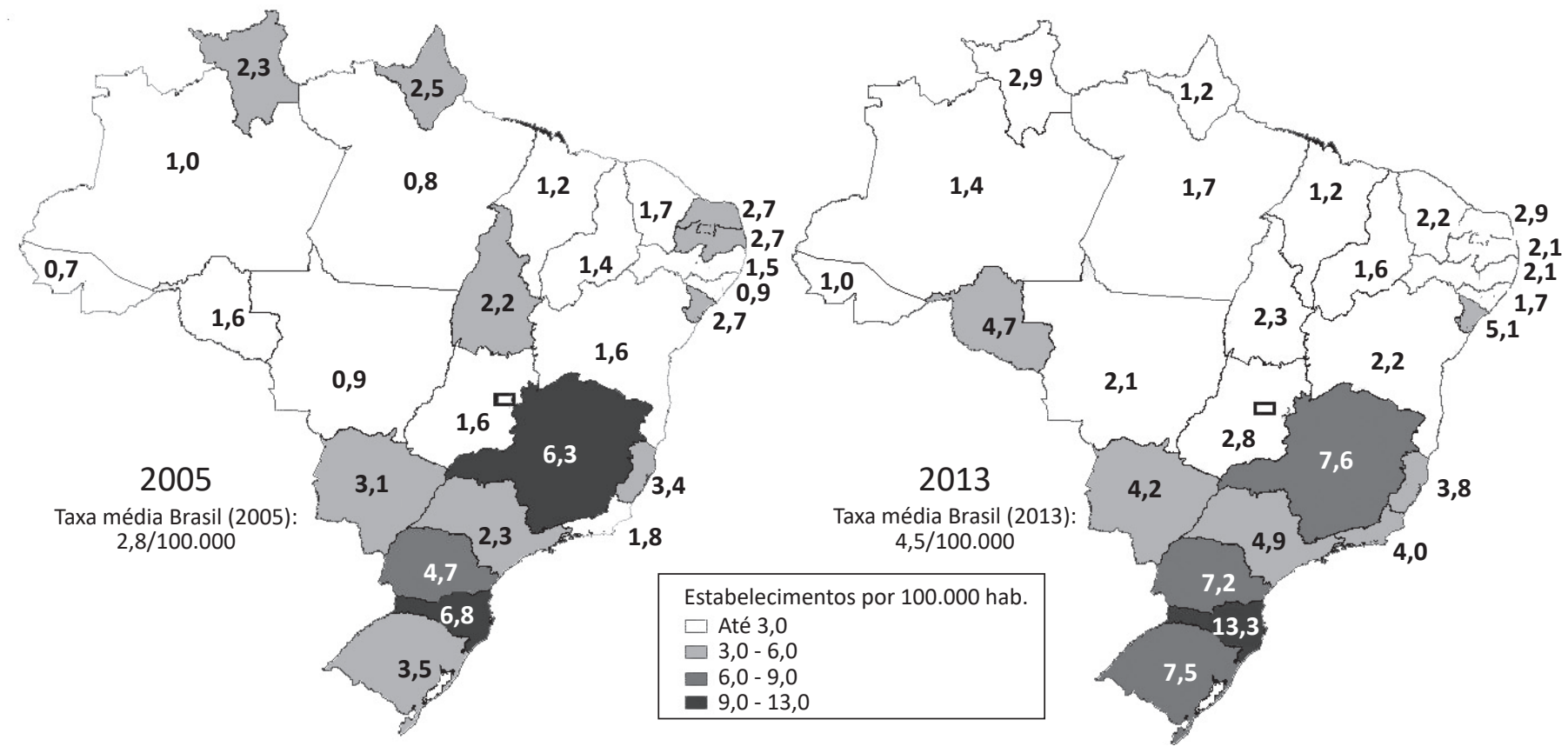

Fonte: DataSUS \& CNES, 2013.

Figura 7 - Segmento privado com fins lucrativos, com serviços complementares contratados pelo SUS e serviços suplementares (D)

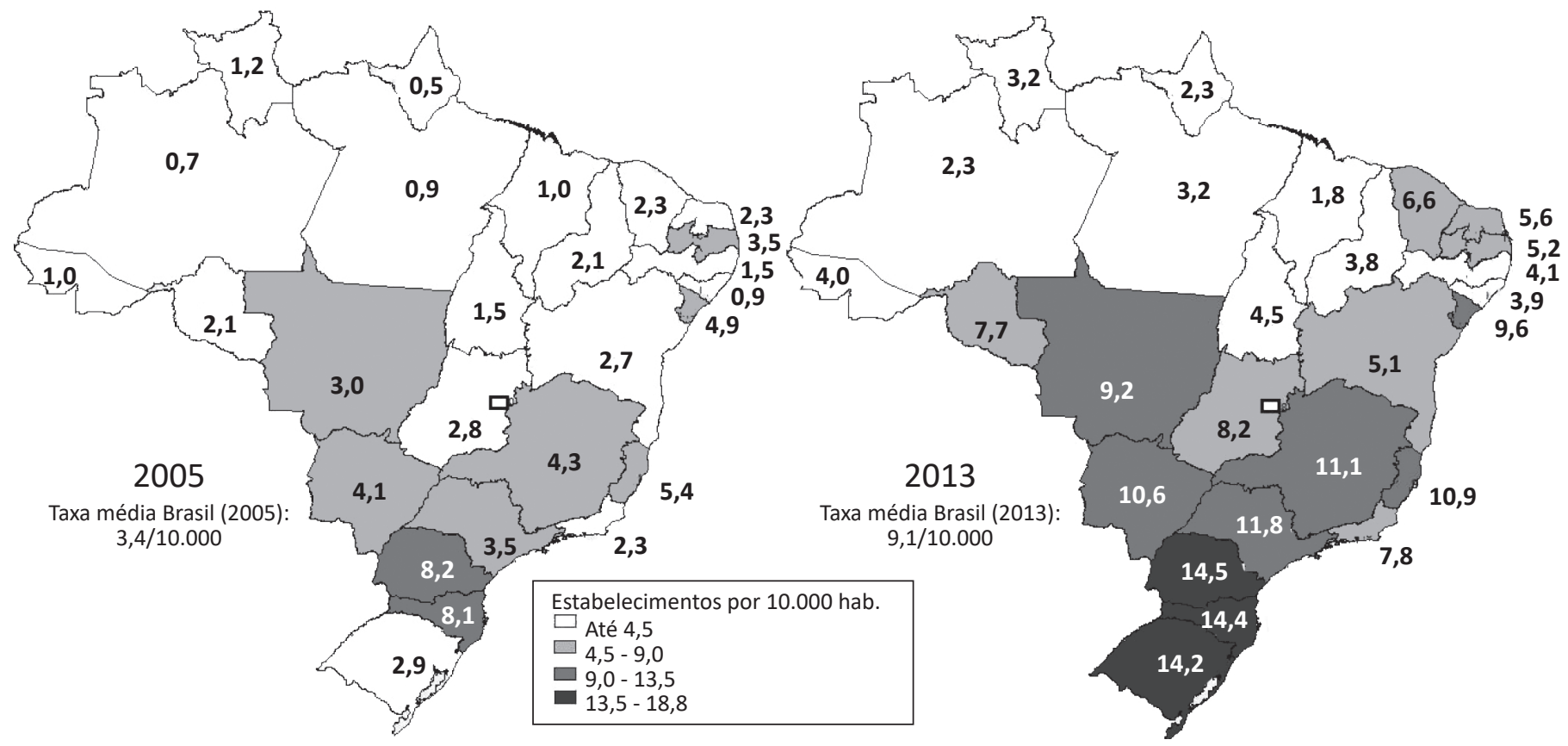

Fonte: DataSUS \& CNES, 2013. 